\title{
Bat fauna of Mato Grosso do Sul, southwestern Brazil
}

\author{
Erich Fischer, $^{1,3}$, Carolina Ferreira Santos ${ }^{1}$, Luiz Felipe Alves da Cunha Carvalho ${ }^{2}$, George Camargo ${ }^{2}$, \\ Nicolay Leme da Cunha ${ }^{2}$, Maurício Silveira ${ }^{2}$, Marcelo Oscar Bordignon ${ }^{1}$ \& Camila de Lima Silva ${ }^{2}$ \\ ${ }^{1}$ Centro de Ciências Biológicas e da Saúde, Universidade Federal de Mato Grosso do Sul, 79070-900 \\ Campo Grande, Mato Grosso do Sul, Brasil. \\ ${ }^{2}$ Programa de Pós-Graduação em Ecologia e Conservação, Universidade Federal de Mato Grosso do Sul, \\ 79070-900 Campo Grande, Mato Grosso do Sul, Brasil. \\ ${ }^{3}$ Corresponding author: Erich Fischer,e-mail: erich.fischer@ufms.br
}

FISCHER, E., SANTOS, C.F., CARVALHO, L.F.A.C., CAMARGO, G., CUNHA, N.L., SILVEIRA, M., BORDIGNON, M.O., SILVA, C.L. Bat fauna of Mato Grosso do Sul, southwestern Brazil. Biota Neotropica. 15(2): e20140066. http://dx.doi.org/10.1590/1676-06032015006614

\begin{abstract}
Bats have been increasingly studied in the last 15 years in Mato Grosso do Sul, and several records were not yet considered in reviews of South American bat distributions. Here, we present the bat species and their distributions in Mato Grosso do Sul based mainly on data compilation from literature, but also on complementary information from zoological collections, and our and colleagues' unpublished records. We found 74 species of bats within 42 genera and seven families already reported in Mato Grosso do Sul. Bat species in this state represent $44 \%$ of the Brazilian's bat species $(\approx 169)$ and $7 \%$ of the world's bat richness $(\approx 1120)$. Phyllostomidae (42) and Molossidae (17) were the richest families. Four species formerly cited for Mato Grosso do Sul are not supported by our compilation, and other 15 species recorded in the vicinity are listed as potential occurrences in this state. We additionally found controversial traits for specimens of Platyrrhinus helleri, and report Eumops dabbenei for the first time in Brazil. Most species were recorded in the regions of Cerrado (60) or Pantanal (57) in Mato Grosso do Sul, but only 16 in the Atlantic Forest. Records of Phyllostomidae species were mostly found in Cerrado and those of Molossidae, in Pantanal. Records in Mato Grosso do Sul determine edges of distribution for at least 22 species of South American bats. The overall known chiropteran fauna of Mato Grosso do Sul is highly diverse and new findings are expected through additional surveys.

Keywords: Cerrado, Chiroptera, geographic distribution, Eumops dabbenei, Pantanal, Platyrrhinus helleri.
\end{abstract}

FISCHER, E., SANTOS, C.F., CARVALHO, L.F.A.C., CAMARGO, G., CUNHA, N.L., SILVEIRA, M., BORDIGNON, M.O., SILVA, C.L. Fauna de morcegos de Mato Grosso do Sul, sudoeste do Brasil. Biota Neotropica. 15(2): e20140066. http://dx.doi.org/10.1590/1676-06032015006614

Resumo: Morcegos têm sido estudados intensivamente em Mato Grosso do Sul nos últimos 15 anos, e vários registros ainda não foram considerados em revisões sobre a distribuição de morcegos sulamericanos. Apresentamos aqui as espécies de morcegos e suas distribuições em Mato Grosso do Sul principalmente com base em dados compilados da literatura, mas também com base em dados complementares de coleção zoológica, e de registros inéditos nossos e de colegas. Encontramos 74 espécies de morcegos pertencentes a 42 gêneros e sete famílias em Mato Grosso do Sul. A riqueza de morcegos nesse estado representa $44 \%$ das espécies brasileiras de morcegos $(\approx 169)$ e $7 \%$ da riqueza mundial de morcegos $(\approx 1120)$. Phyllostomidae $(42)$ e Molossidae (17) foram as famílias mais ricas. Quatro espécies reportadas anteriormente para Mato Grosso do Sul não são sustentadas com base em nossa compilação, e outras 15 espécies registradas na vizinhança são listadas como ocorrências potenciais no estado. Adicionalmente, encontramos características controversas em espécimes de Platyrrhinus helleri, e reportamos Eumops dabbenei pela primeira vez no Brasil. A maioria das espécies foi registrada nas regiões de Cerrado (60) ou Pantanal (57) em Mato Grosso do Sul, e apenas 16 em Mata Atlântica. Registros de Phyllostomidae foram encontrados principalmente em Cerrado e de Molossidae, no Pantanal. Sítios em Mato Grosso do Sul determinam limites de distribuição para pelo menos 22 espécies de morcegos sul americanos. A fauna de morcegos conhecida em Mato Grosso do Sul é bastante diversa, e novos registros são esperados por meio de inventários adicionais.

Palavras-chave: Cerrado, Chiroptera, distribuição geográfica, Eumops dabbenei, Pantanal, Platyrrhinus helleri. 


\section{Introduction}

Although there are some old reports on bat occurrences in Mato Grosso do Sul (e.g. Vieira 1945), almost all knowledge about the chiropteran fauna in this state has 30 years of history, and most records have been reported in the last 10-15 years (e.g. Pulchério-Leite et al. 1998, Taddei \& Uieda 2001, Camargo \& Fischer 2005, Bordignon 2006, Santos et al. 2010, Silveira et al. 2011). Luiz Onofre Irineu de Souza has provided the first noticeable impetus to the knowledge of bats in Mato Grosso do Sul. He has begun in 1982 the section of chiropterans of the zoological collection of the Universidade Federal de Mato Grosso do Sul (UFMS), and has incorporated 82 specimens of 21 species over a decade. This was the foremost collection of Mato Grosso do Sul's bat fauna in 1997, when Valdir Antônio Taddei has initiated a second pronounced impetus to the knowledge of bats in the state, founding the chiropteran collection of the Universidade para o Desenvolvimento do Estado e da Região do Pantanal (UNIDERP-Anhanguera). Thereafter, supported by these two collections of bats that include more than 5000 specimens today, the bat fauna has been increasingly investigated in Mato Grosso do Sul.

As the knowledge is quite recent, several records of bats in Mato Grosso do Sul have not yet been considered for South American bat distributions (e.g. Gardner 2008) nor included in reviews of the Brazilian bat fauna (Bianconi \& Pedro 2007, Fabian \& Gregorin 2007, Nogueira et al. 2007a, 2007b, Peracchi \& Nogueira 2007, Zortéa 2007). For instance, the most recent review of the Brazil's bat fauna (Tavares et al. 2008) did not include 37 of the 74 species that we list here for Mato Grosso do Sul. The Pantanal and the midwestern Brazil are regions still identified as gaps of data on bat species occurrences (Tavares et al. 2008, Bernard et al. 2011), a condition that has been reversed. Here, we review the known chiropteran species and their distributions in Mato Grosso do Sul, and add unpublished data which include the first record of Eumops dabbenei (Molossidae) in Brazil. The large number of species found and the distribution of study sites show that the knowledge on Mato Grosso do Sul's bat fauna is not incipient, though recent.

\section{Methods}

The state of Mato Grosso do Sul in central South America comprises the borders of the major continental morfoclimatic domains of Cerrado and Atlantic Forest, and the transitional morfoclimatic zone of Pantanal (Ab'Saber 2000). Environmental differences among Cerrado, Pantanal and Atlantic Forest can determine floristic and faunal variations (e.g. Alho et al. 2011a), thus we present records of bats according to these domains. We formerly searched for records of bat species in Mato Grosso do Sul reported in the literature, using as keywords the names of species and families, and combinations of the words (in English and Portuguese): bats, Chiroptera, distribution, occurrence, Cerrado, Chaco, Mato Grosso, Pantanal. Searches included databases of Scielo, Web of Science and Google. We then selected only records described as geographic coordinates or by names of places which allowed geographical identification. Complementary, we looked for additional records in zoological collections through the speciesLink (http://splink.cria.org.br/) and in the UFMS collection (ZUFMS), and ultimately among our unpublished data and on those kindly offered by the colleagues Alan Eriksson, Gustavo Graciolli, Nayara F. Carvalho, Paulo R. de Souza, and Wilson Uieda. Bat species nomenclature follows Simmons (2005), except Artibeus planirostris and Natalus macrourus that follow Lim et al. (2004) and Garbino \& Tejedor (2012) respectively. We conservatively used Platyrrhinus helleri sensu Simmons (2005) because specimens collected in Mato Grosso do Sul differed from the expected according to Velazco et al. (2010a). Thus we described some traits of two P. helleri specimens and compared with those described by Velazco et al. (2010a). We also described traits of one Eumops dabbenei specimen, identified based on Kiser (1995), Barquez et al. (1999), Gregorin \& Taddei (2002) and Eger (2007).

For preparation of distribution maps we used geographic coordinates described in the published studies or collection records, and centroids when the information consisted of names of farms, towns, or villages. We cited geographic coordinates for unpublished records included in the maps (Appendix 1). In cases of species registered twice or more in a same site or nearby $(<20 \mathrm{~km})$, we cited one or two sources in the following order: records published in scientific journals, thesis or dissertations, specimens in zoological collections, and unpublished data. Point size in the distribution maps covers a circular area of $9.3 \mathrm{~km}$ of radius. Overlapping points of different species in a same map were slightly dislocated to improve visualization. Maps show some points out of Mato Grosso do Sul when part of studies cited as sources for sites in the state. We finally plotted all sites of bat records surrounded by an arbitrary buffer area of $20 \mathrm{~km}$ to provide a roughly notion of the states' territory uncovered for bat surveys.

\section{Results and discussion}

\section{Bat species of Mato Grosso do Sul}

We compiled 74 species of bats within 42 genera and seven families already registered in the state of Mato Grosso do Sul (Table 1). This number of species is $20 \%$ higher than that listed some years ago (Cáceres et al. 2008), and close to the richness of bats reported for other Brazilian states with longer history of bat surveys, as Paraná (64; Passos et al. 2010), Rio de Janeiro (77; Peracchi \& Nogueira 2010), São Paulo (79; Vivo et al. 2011), and Minas Gerais (80; Tavares et al. 2010). Most species (62) were found in two or more sites, whereas the remaining 12 species were recorded in one site only: eight phyllostomids (Micronycteris sanborni, Trachops cirrhosus, Uroderma bilobatum, U. magnirostrum, Vampyrodes caraccioli, Lonchophylla mordax, Lionycteris spurrelli, and Rhinophylla pumilio), three molossids (Eumops dabbenei, E. bonariensis, and Tadarida brasiliensis), and one vespertilionid (Lasiurus cinereus). Thus additional records of these species are expected to strengthen their occurrences in this state, mainly Lionycteris spurrelli, Trachops cirrhosus, and Tadarida brasiliensis which were registered only in the state's boundaries (Bordignon 2006, Cunha et al. 2011, Santos \& Bordignon 2011). To accept the occurrence of Rhinophylla pumilio as valid requires additional records, since there is no information whether the individual was deposited in a collection (Coelho 2005). Additional records are also desirable for Artibeus fimbriatus, as the two specimens reported in the central region of Mato Grosso do Sul are not accessible in local collections (Deus et al. 2003, Cáceres et al. 2008), and other individuals were 
Table 1. Bat species $(n=74)$ recorded in the Pantanal (PA), Cerrado (CE), and Atlantic Forest (AF) domains, and references to the figures of distribution, in the State of Mato Grosso do Sul, Brazil.

\begin{tabular}{|c|c|c|c|c|}
\hline \multirow{2}{*}{$\begin{array}{l}\text { Families } \\
\text { Subfamilies } \\
\text { Species }\end{array}$} & \multicolumn{3}{|c|}{ Domains } & \multirow[b]{2}{*}{ Figures of distribution } \\
\hline & $\mathbf{P A}$ & $\mathrm{CE}$ & $\overline{\mathrm{AF}}$ & \\
\hline \multicolumn{5}{|l|}{ Phyllostomidae Gray, 1825} \\
\hline \multicolumn{5}{|l|}{ Phyllostominae Gray, 1825} \\
\hline Lophostoma brasiliense Peters, 1866 & $\mathrm{X}$ & $\mathrm{X}$ & & $1 \mathrm{~A}$ \\
\hline Lophostoma silvicolum d'Orbigny, 1836 & $\mathrm{X}$ & $\mathrm{X}$ & & $1 \mathrm{~A}$ \\
\hline Macrophyllum macrophyllum (Schinz, 1821) & & $\mathrm{X}$ & & $1 \mathrm{~A}$ \\
\hline Micronycteris sanborni Simmons, 1996 & & $\mathrm{X}$ & & $1 \mathrm{~B}$ \\
\hline Micronycteris minuta (Gervais, 1856) & $\mathrm{X}$ & $\mathrm{X}$ & & $1 \mathrm{~B}$ \\
\hline Micronycteris megalotis Gray, 1842 & $\mathrm{X}^{\mathrm{a}}$ & $\mathrm{X}$ & & $1 \mathrm{~B}$ \\
\hline Chrotopterus auritus (Peters, 1856) & $\mathrm{X}$ & $\mathrm{X}$ & $\mathrm{X}$ & $1 \mathrm{C}$ \\
\hline Lonchorhina aurita Tomes, 1863 & & $\mathrm{X}$ & & $1 \mathrm{C}$ \\
\hline Mimon bennettii (Gray, 1838) & $\mathrm{X}$ & $\mathrm{X}$ & & $1 \mathrm{D}$ \\
\hline Mimon crenulatum (E. Geoffroy, 1803) & $\mathrm{X}$ & & & $1 \mathrm{D}$ \\
\hline Phylloderma stenops Peters, 1865 & $\mathrm{X}$ & $\mathrm{X}$ & & $1 \mathrm{D}$ \\
\hline Phyllostomus elongatus (E. Geoffroy, 1810) & $\mathrm{X}^{\mathrm{a}}$ & $\mathrm{X}$ & & $1 \mathrm{E}$ \\
\hline Phyllostomus hastatus (Pallas, 1767) & $\mathrm{X}$ & $\mathrm{X}$ & $\mathrm{X}$ & $1 \mathrm{E}$ \\
\hline Phyllostomus discolor Wagner, 1843 & $\mathrm{X}$ & $\mathrm{X}$ & $\mathrm{X}$ & $1 \mathrm{E}$ \\
\hline Tonatia bidens (Spix, 1823) & $\mathrm{X}$ & $\mathrm{X}$ & & $1 \mathrm{~F}$ \\
\hline Trachops cirrhosus (Spix, 1823) & & $\mathrm{X}$ & & $1 \mathrm{~F}$ \\
\hline Vampyrum spectrum (Linnaeus, 1758) & $\mathrm{X}$ & & & $1 \mathrm{~F}$ \\
\hline \multicolumn{5}{|l|}{ Stenodermatinae Gervais, 1856} \\
\hline Artibeus cinereus (Gervais, 1856) & & $\mathrm{X}$ & & $2 \mathrm{~A}$ \\
\hline Artibeus fimbriatus Gray, 1838 & & $\mathrm{X}$ & $\mathrm{X}$ & $2 \mathrm{~A}$ \\
\hline Artibeus planirostris (Spix, 1823) & $\mathrm{X}$ & $\mathrm{X}$ & $\mathrm{X}$ & $2 \mathrm{~A}$ \\
\hline Artibeus obscurus (Schinz, 1821) & $\mathrm{X}^{\mathrm{b}}$ & $\mathrm{X}$ & $\mathrm{X}$ & $2 \mathrm{~B}$ \\
\hline Artibeus lituratus (Olfers, 1818) & $\mathrm{X}$ & $\mathrm{X}$ & $\mathrm{X}$ & $2 \mathrm{~B}$ \\
\hline Chiroderma villosum Peters, 1860 & $\mathrm{X}$ & $\mathrm{X}$ & & $2 \mathrm{C}$ \\
\hline Chiroderma doriae O. Thomas, 1891 & $\mathrm{X}$ & $\mathrm{X}$ & $\mathrm{X}$ & $2 \mathrm{C}$ \\
\hline Platyrrhinus helleri (Peters, 1866) & $\mathrm{X}$ & $\mathrm{X}$ & & $2 \mathrm{D}$ \\
\hline Platyrrhinus lineatus (E. Geoffroy, 1810) & $\mathrm{X}$ & $\mathrm{X}$ & $\mathrm{X}$ & $2 \mathrm{D}$ \\
\hline Pygoderma bilabiatum (Wagner, 1843) & & $\mathrm{X}$ & $\mathrm{X}$ & $2 \mathrm{E}$ \\
\hline Uroderma bilobatum Peters, 1866 & $\mathrm{X}$ & & & $2 \mathrm{E}$ \\
\hline Uroderma magnirostrum Davis, 1868 & & $\mathrm{X}$ & & $2 \mathrm{E}$ \\
\hline Vampyressa pusilla (Wagner, 1843) & $\mathrm{X}$ & $\mathrm{X}$ & & $2 \mathrm{E}$ \\
\hline Vampyrodes caraccioli (Thomas, 1889) & $\mathrm{X}$ & & & $2 \mathrm{E}$ \\
\hline Sturnira lilium (E. Geoffroy, 1810) & $\mathrm{X}$ & $\mathrm{X}$ & $\mathrm{X}$ & $2 \mathrm{~F}$ \\
\hline \multicolumn{5}{|l|}{ Desmodontinae Bonaparte, 1845} \\
\hline Desmodus rotundus (E. Geoffroy, 1810) & $\mathrm{X}$ & $\mathrm{X}$ & $\mathrm{X}$ & $3 \mathrm{~A}$ \\
\hline Diaemus youngi (Jentink, 1893) & $\mathrm{X}$ & & & $3 \mathrm{~A}$ \\
\hline \multicolumn{5}{|l|}{ Glossophaginae Bonaparte, 1845} \\
\hline Anoura geoffroyi Gray, 1838 & $\mathrm{X}$ & $\mathrm{X}$ & & $3 \mathrm{~B}$ \\
\hline Anoura caudifer (E. Geoffroy, 1818) & $\mathrm{X}$ & $\mathrm{X}$ & & $3 \mathrm{~B}$ \\
\hline Glossophaga soricina (Pallas, 1766) & $\mathrm{X}$ & $\mathrm{X}$ & $\mathrm{X}$ & $3 \mathrm{C}$ \\
\hline Lonchophylla dekeyseri Tad.Viz. Saz.,1983 & & $\mathrm{X}$ & & $3 \mathrm{D}$ \\
\hline Lonchophylla mordax Thomas, 1903 & & $\mathrm{X}$ & & $3 \mathrm{D}$ \\
\hline Lionycteris spurrelli Thomas, 1913 & & $\mathrm{X}$ & & $3 \mathrm{D}$ \\
\hline \multicolumn{5}{|l|}{ Carolliinae Miller, 1924} \\
\hline Carollia perspicillata (Linnaeus, 1758) & $\mathrm{X}$ & $\mathrm{X}$ & $\mathrm{X}$ & $3 \mathrm{E}$ \\
\hline Rhinophylla pumilio Peters, 1865 & & $\mathrm{X}$ & & $3 \mathrm{E}$ \\
\hline \multicolumn{5}{|l|}{ Emballonuridae Gervais, 1855} \\
\hline \multicolumn{5}{|l|}{ Embalonurinae Gervais, 1855} \\
\hline Peropteryx macrotis (Wagner, 1843) & $\mathrm{X}^{\mathrm{a}}$ & $\mathrm{X}$ & & $3 \mathrm{~F}$ \\
\hline Rhynchonycteris naso (Wied-Neuwied, 1820) & $\mathrm{X}$ & & & $3 \mathrm{~F}$ \\
\hline
\end{tabular}


Table 1. Continued.

\begin{tabular}{|c|c|c|c|c|}
\hline \multirow{2}{*}{$\begin{array}{l}\text { Families } \\
\text { Subfamilies } \\
\text { Species }\end{array}$} & \multicolumn{3}{|c|}{ Domains } & \multirow[b]{2}{*}{ Figures of distribution } \\
\hline & PA & $\mathbf{C E}$ & $\mathbf{A F}$ & \\
\hline \multicolumn{5}{|l|}{ Molossidae Gervais, 1856} \\
\hline \multicolumn{5}{|l|}{ Molossinae Gervais, 1856} \\
\hline Cynomops abrasus (Temminck, 1827) & $\mathrm{X}$ & $\mathrm{X}$ & & $4 \mathrm{~A}$ \\
\hline Cynomops planirostris (Peters, 1865) & $\mathrm{X}$ & $\mathrm{X}$ & & $4 \mathrm{~A}$ \\
\hline Eumops dabbenei Thomas, 1914 & $\mathrm{X}$ & & & $4 \mathrm{~A}$ \\
\hline Eumops bonariensis (Peters, 1874) & & $\mathrm{X}$ & & $4 \mathrm{~A}$ \\
\hline Eumops glaucinus (Wagner, 1843) & $\mathrm{X}$ & $\mathrm{X}$ & & $4 \mathrm{~B}$ \\
\hline Eumops patagonicus Thomas, 1924 & $\mathrm{X}$ & & & $4 \mathrm{~B}$ \\
\hline Eumops perotis (Schinz, 1821) & $\mathrm{X}$ & & & $4 \mathrm{~B}$ \\
\hline Eumops auripendulus (Shaw, 1800) & $\mathrm{X}$ & $\mathrm{X}^{\mathrm{c}}$ & & $4 \mathrm{~B}$ \\
\hline Molossops temminckii (Burmeister, 1854) & $\mathrm{X}$ & $\mathrm{X}$ & & $4 \mathrm{C}$ \\
\hline Molossus rufus E. Geoffroy, 1805 & $\mathrm{X}$ & $\mathrm{X}$ & & $4 \mathrm{D}$ \\
\hline Molossus molossus (Pallas, 1766) & $\mathrm{X}$ & $\mathrm{X}$ & $\mathrm{X}$ & $4 \mathrm{D}$ \\
\hline Molossus pretiosus Miller, 1902 & $\mathrm{X}$ & & & $4 \mathrm{D}$ \\
\hline Nyctinomops macrotis (Gray, 1840) & & $\mathrm{X}$ & & $4 \mathrm{E}$ \\
\hline Nyctinomops laticaudatus (E. Geoffroy, 1805) & $\mathrm{X}$ & $\mathrm{X}$ & & $4 \mathrm{E}$ \\
\hline Promops centralis Thomas, 1915 & $\mathrm{X}$ & & & $4 \mathrm{~F}$ \\
\hline Promops nasutus (Spix, 1823) & $\mathrm{X}$ & & & $4 \mathrm{~F}$ \\
\hline Tadarida brasiliensis I. Geoffroy, 1824 & $\mathrm{X}$ & & & $4 \mathrm{~F}$ \\
\hline \multicolumn{5}{|l|}{ Vespertilionidae Gray, 1821} \\
\hline \multicolumn{5}{|l|}{ Vespertilioninae Gray, 1821} \\
\hline \multicolumn{5}{|l|}{ Eptesicus furinalis (d'Orbigny, 1847) } \\
\hline Eptesicus brasiliensis (Desmarest, 1819) & $\mathrm{X}$ & $\mathrm{X}$ & & $5 \mathrm{~A}$ \\
\hline Lasiurus blossevillii (Lesson \& Garnot, 1826) & & $\mathrm{X}$ & & $5 \mathrm{~A}$ \\
\hline Lasiurus cinereus (Beauvois, 1796) & $\mathrm{X}$ & $\mathrm{X}$ & & $5 \mathrm{~B}$ \\
\hline Lasiurus ega (Gervais, 1856) & & $\mathrm{X}^{\mathrm{c}}$ & & $5 \mathrm{~B}$ \\
\hline Myotinae Tate, 1942 & $\mathrm{X}$ & $\mathrm{X}$ & & $5 \mathrm{~B}$ \\
\hline \multicolumn{5}{|l|}{ Myotis nigricans (Schinz, 1821) } \\
\hline Myotis simus Thomas, 1901 & $\mathrm{X}$ & $\mathrm{X}$ & $\mathrm{X}$ & $5 \mathrm{C}$ \\
\hline Myotis riparius Handley, 1960 & $\mathrm{X}$ & & & $5 \mathrm{D}$ \\
\hline Myotis albescens (E. Geoffroy, 1806) & $\mathrm{X}$ & $\mathrm{X}$ & & $5 \mathrm{D}$ \\
\hline $\begin{array}{l}\text { Mormoopidae Saussure, } 1860 \\
\quad \text { Pteronotus parnellii (Gray, 1843) }\end{array}$ & $\mathrm{X}$ & $\mathrm{X}$ & & $5 \mathrm{D}$ \\
\hline Noctilionidae Gray, 1821 & & $\mathrm{X}$ & & $5 \mathrm{E}$ \\
\hline Noctilio leporinus (Linnaeus, 1758) & & & & \\
\hline Noctilio albiventris Demarest, 1818 & $\mathrm{X}$ & $\mathrm{X}$ & & $5 \mathrm{~F}$ \\
\hline Natalidae Gray, 1866 & $\mathrm{X}$ & $\mathrm{X}$ & $\mathrm{X}$ & $5 \mathrm{~F}$ \\
\hline Natalus macrourus (Gervais, 1856) & $\mathrm{X}^{\mathrm{a}}$ & $\mathrm{X}$ & & $5 \mathrm{E}$ \\
\hline
\end{tabular}

${ }^{\mathrm{a} O c c u r r e n c e}$ in the Pantanal border.

${ }^{b}$ Occurrence at the southern limit of Pantanal.

${ }^{\mathrm{c}}$ In urban zone, Campo Grande.

captured in the limit with Paraná (Ortêncio-Filho et al. 2010, Zanon 2010).

Based on our criteria, five species formerly cited for Mato Grosso do Sul were not included in the present checklist (Table 1). One Diphylla ecaudata individual was described without a location (Alho et al. 2011b), so we keep it out of the states' checklist. Molossus currentium was listed by Fabian \& Gregorin (2007), but it was a mistake since the record is actually $3 \mathrm{~km}$ away, in Paraguay (López-Gonzáles \& Presley 2001). Likewise, Myotis ruber was recorded $1 \mathrm{~km}$ away from the state (Coelho 2005). Therefore, Molossus currentium and Myotis ruber presumably occur in Mato Grosso do Sul in spite they have not yet been recorded. Tavares et al. (2008) pointed out the occurrence of Tonatia saurophila based on Williams et al. (1995a); however, it was another mistake because
Williams et al. (1995a) cited only T. bidens in Mato Grosso do Sul. Thus, the occurrence of $T$. saurophila remains unknown in this state, though expected due to records in Bolivia (Aguirre 2007). One specimen of Micronycteris schmidtorum was listed in Cáceres et al. (2008) due to misidentification, reviewed to M. sanborni in Santos et al. (2010). Therefore, M. schmidtorum follows unreported for Mato Grosso do Sul. Recently, Siles et al. (2013) described the species Micronycteris yatesi based on specimens from Bolivia formerly identified as M. sanborni. Due to geographical proximity to Bolivia and morphological similarities between both species, the only specimen from Mato Grosso do Sul assigned as M. sanborni (Santos et al. 2010) might actually belong to $M$. yatesi. Once confirmed, it would be the first record of $M$. yatesi in Brazil, and this new species would no longer be considered as endemic to Bolivia 
Bats of Mato Grosso do Sul

Table 2. Five traits of Platyrrhinus helleri and P. incarum bats (Phyllostomidae) described by Velazco et al. (2010a), and for specimens from Mato Grosso do Sul (MS), Brazil.

\begin{tabular}{llll}
\hline Traits & Platyrrhinus incarum & Platyrrhinus helleri & Specimens from MS \\
\hline Noseleaf vibrissae (n) & 8 & 7 & 7 \\
Ventral fur color & Bicolor, light brown & Unicolor, light grey & Unicolor, pale \\
Uropatagium margin & Inverted U-shape & Inverted V-shape & Inverted V-shape \\
Length of metacarpal III & Longer than metacarpal V & Similar to metacarpal V & Similar to metacarpal V \\
Dorsal stripe & Narrow & Wide and bright & Wide and bright \\
\hline
\end{tabular}

(Siles et al. 2013). In addition, if so, M. yatesi should substitute $M$. sanborni in the present state's bat checklist.

At least 15 additional species of bats are potentially expected in Mato Grosso do Sul based on their occurrences in the vicinity, in the Paraguay basin or in sites of Cerrado, Atlantic Forest or Chaco: Glyphonycteris behnii (Nogueira et al. 2007a, Tavares et al. 2008), Mesophylla macconnelli (Aguirre 2007, Tavares et al. 2008), Artibeus anderseni, A. gnomos (Gonçalves \& Gregorin 2004), A. glaucus (Aguirre 2007), Platyrrhinus brachycephalus (Silva \& Marques 2010), P. masu, Choeroniscus minor (Aguirre 2007), Saccopteryx bilineata (Oliveira et al. 2002), Molossops neglectus (Bernardi et al. 2007), Nyctinomops aurispinosus (Aguirre 2007, Tavares et al 2008), Eptesicus diminutus, Histiotus macrotus (Willig et al. 2000, Tavares et al. 2008), Histiotus velatus (Aguirre 2007, Tavares et al. 2008), and Pteronotus gymnonotus (Gonçalves \& Gregorin 2004). These potential species summed to Diphylla ecaudata, Molossus currentium, Myotis ruber and Tonatia saurophila, indicate that almost one hundred bat species might occur in the state of Mato Grosso do Sul.

\section{Specimens of Platyrrhinus helleri and Eumops dabbenei}

Some external traits of two specimens of Platyrrhinus helleri (sensu Simmons 2005) from Mato Grosso do Sul (ZUFMS 0241, 0264) match $P$. helleri (sensu Velazco et al. 2010a) rather than $P$. incarum (Table 2), as would be expected. Based on morphological and molecular data, Velazco \& Patterson (2008) and Velazco et al. (2010a) proposed $P$. incarum as a valid species whose distribution includes the northern and midwestern Brazil, in the state of Mato Grosso, $387 \mathrm{~km}$ north than our northernmost record. They also suggested that $P$. helleri (sensu Velazco et al. 2010a) does not occur in Brazil, and presents the southern edge of distribution in Colombia, Venezuela and Ecuador. Thus far the external traits of specimens from Mato Grosso do Sul may indicate either an unlikely first occurrence of $P$. helleri (sensu Velazco et al. 2010a) in Brazil, or that those external characteristics (Table 2) are not useful to discriminate between $P$. incarum and $P$. helleri (sensu Velazco et al. 2010a), or even an undescribed taxon in the region. Therefore, we highlight that specimens of $P$. helleri (sensu Simmons 2005) in Mato Grosso do Sul deserve a deep taxonomic approach before assign them to a species proposed by Velazco et al. (2010a).

Among bat species found in Mato Grosso do Sul, we report here the first occurrence of Eumops dabbenei in Brazil. One adult male was mistnetted at sunset in the edge of a semideciduous forest, in the Pantanal. The specimen presented ears that do not extend over the nose when laid forward, and antitragus shorter than those of E. perotis and E. trumbulli, the other congeneric species with forearm longer than $70 \mathrm{~mm}$ (Barquez et al. 1999, Gregorin \& Taddei 2002, Fabián \& Gregorin 2007). Twelve traits measured on the male $E$. dabbenei fall within the range reported to the species; other six measures are either larger (breadth across canines and breadth across molars) or shorter (tail length, mandibular length, mandibular toothrow length, and maxillary toothrow length) for $E$. dabbenei from Pantanal than for those from elsewhere (Table 3). Eumops dabbenei appears to be rare, with few specimens deposited in zoological collections (Barquez et al. 1999, Tavares et al. 2008). Even so, its occurrence in Brazil, mainly in the southern Pantanal, might be expected due to previous records in Paraguay, 15 to $25 \mathrm{~km}$ from Mato Grosso do Sul (Redford \& Eisenberg 1992, Gregorin \& Taddei 2002, Eger 2007).

\section{Bat distributions in Mato Grosso do Sul}

Of the 74 bat species compiled for Mato Grosso do Sul, 60 were found in Cerrado, 57 in Pantanal, and 17 in Atlantic Forest. Fifteen were exclusively registered in Cerrado, 14 solely in Pantanal, and none was found only in Atlantic Forest (Table 1). All five subfamilies of Phyllostomidae were present in the three domains, but low proportions of Phyllostominae and Glossophaginae species (18\% and $17 \%$, respectively) were registered in Atlantic Forest; for the other subfamilies this proportion was about $50 \%$ (Table 1). Beyond phyllostomids, only Molossus molossus, Myotis nigricans, and Noctilio albiventris were found in Mato Grosso do Sul's Atlantic Forest. This poor bat fauna in this domain may reflect a very low survey effort rather than a region deprived of bat species in Mato Grosso do Sul. The number of species in the states' Atlantic Forest reaches only $14 \%$ of those listed for this domain (cf. Paglia et al. 2012). Therefore, even accounting for the relatively small area and the restricted latitudinal range of the Atlantic Forest in Mato Grosso do Sul, increased bat surveys in this region should add several unnoticed species. In contrast, the number of bat species in the states' Cerrado region reaches $60 \%$ of that in the whole Brazilian Cerrado, and the number of species in the states' Pantanal region does $95 \%$ of that in this domain in Brazil (cf. Paglia et al. 2012). This high proportion of species from Brazilian Pantanal notably occurs because most of this domain is in Mato Grosso do Sul.

Records of Phyllostominae species in Mato Grosso do Sul were mostly distributed in Cerrado rather than in Pantanal. Seven species (Macrophyllum macrophyllum, Micronycteris spp., Lonchorhina aurita, Mimon bennettii, and Trachops cirrhosus) were mainly recorded in Cerrado, and three (Lophostoma silvicolum, Mimon crenulatum and Vampyrum spectrum) mainly in Pantanal (Figure 1). Likewise, five 
Table 3. Measures of one male Eumops dabbenei (Molossidae) collected in the Pantanal, Mato Grosso do Sul (MS), Brazil, and range of measurements (or single value if only one available) for this species elsewhere (references: $1=$ Barquez et al. 1999; $2=$ Souza et al. 2008; 3 = Harrison et al. 1979; 4 = Ochoa \& Ibanez 1985; 5 = McWilliams et al. 2002; 6 = Eger 1977; $7=$ Redford \& Eisenberg 1992).

\begin{tabular}{llll}
\hline Traits & Specimen from MS & Range & References \\
\hline Total body length (mm) & 168 & $145-190$ & $1,2,7$ \\
Weight (g) & 77 & $74-77$ & 1,7 \\
Tail length (mm) & 54 & $55-64$ & $1,2,7$ \\
Braincase length (mm) & 30.8 & $29.6-33.8$ & $1,2,3,4,5,6$ \\
Braincase breadth (mm) & 14.2 & $12.3-14.2$ & 1,2 \\
Breadth across canines (mm) & 8.5 & 8.0 & 1 \\
Breadth across molars (mm) & 14.3 & $13.2-13.7$ & 1,4 \\
Condylobasal length (mm) & 28.3 & $28.4-30.8$ & $1,2,3,4,5$ \\
Ear length (mm) & 24.9 & $24.0-31.7$ & $1,2,7$ \\
Interorbital width less (mm) & 8.9 & $6.1-10.8$ & $1,2,4$ \\
Postorbital constriction (mm) & 6.3 & $5.9-10.8$ & $2,3,5,6$ \\
Mandibular length (mm) & 23.2 & $23.6-24.9$ & 1,3 \\
Mandibular toothrow length (mm) & 14.1 & $14.3-14.9$ & 1,3 \\
Mastoid breadth (mm) & 16.5 & $16.0-17.1$ & $1,3,5,6$ \\
Maxillary toothrow length (mm) & 12.1 & $12.5-13.4$ & $1,3,4,5,6$ \\
Zygomatic breadth (mm) & 20.0 & $16.5-20.4$ & $2,3,4,5,6$ \\
Forearm length (mm) & 77.0 & $75.2-78.5$ & $1,2,3,4,6,7$ \\
Hind foot length (mm) & 13.5 & $12.0-18.0$ & $2,3,7$ \\
\hline
\end{tabular}

Stenodermatinae (Artibeus cinereus, A. fimbriatus, A. obscurus, Pygoderma bilabiatum, and Uroderma magnirostrum) were solely or more commonly registered in Cerrado, and just two rare species (Uroderma bilobatum and Vampyrodes caraccioli) were found exclusively in the Pantanal (Figure 2). In the other subfamilies, records of Diaemus youngi were distributed in Pantanal, whereas Anoura spp., Lonchophylla spp., Lionycteris spurrelli, and Rhinophylla pumilio were exclusively or more frequently reported in Cerrado (Figure 3). In total, 18 species of Phyllostomidae appear to have their occurrences somehow favored in Cerrado, and six in Pantanal. Additional 18 phyllostomid species were distributed over both regions without an apparent tendency to either Cerrado or Pantanal.

In contrast to Phyllostomidae, records of Emballonuridae and Molossidae species were largely distributed in Pantanal rather than in Cerrado. Among Emballonuridae, Rhynchonycteris naso was recorded only in Pantanal and Peropteryx macrotis in both Cerrado and Pantanal (Figure 3F). For Molossidae, 11 species (Cynomops abrasus, Eumops dabbenei, E. glaucinus, E. patagonicus, E. perotis, E. auripendulus, Molossus pretiosus, Nyctinomops laticaudatus, Promops centralis, P. nasutus, and Tadarida brasiliensis) were mostly or exclusively registered in Pantanal, two species (Eumops bonariensis and Nyctinomops macrotis) were found in Cerrado only, and four species (Cynomops planirostris, Molossops temminckii, Molossus rufus, and M. molossus) did not present a clear tendency of records between Pantanal or Cerrado in Mato Grosso do Sul (Figure 4). Distributions of Vespertilionidae species in Mato Grosso do Sul seem to present opposite tendencies between the subfamilies Vespertilioninae and Myotinae (Figure 5A-D). The former presented two species (Eptesicus brasiliensis and Lasiurus cinereus) exclusively in Cerrado and one (Lasiurus ega) more frequently reported in Pantanal, and the latter presented three species (Myotis albescens, $M$. riparius, and $M$. simus) more frequently recorded in Pantanal and none species clearly distributed toward Cerrado. Other Vespertilioninae (Eptesicus furinalis and
Lasiurus blossevillii) and Myotinae (Myotis nigricans) showed no tendency of records between domains. In the remaining families, Pteronotus parnellii and Natalus macrourus were exclusively or more commonly found in Cerrado (Figure 5E), and Noctilio spp. in Pantanal (Figure 5F).

\section{Notes on bat distributions in South America}

Sites in Mato Grosso do Sul determine boundaries of distributions for several bats in South America. Findings of Mimon bennettii in Pantanal expand its distribution westernward, and those of Micronycteris megalotis in Serra da Bodoquena fill a gap on its previously known distribution map (Gardner 2008, Eriksson et al. 2011, Oliveira et al. 2011). Records of Phylloderma stenops in Mato Grosso do Sul support that its geographical range includes most of the Cerrado domain (Pulchério-Leite et al. 1998, Esbérard \& Faria 2006, Alho et al. 2011b). Sites of occurrence for Vampyrum spectrum and Artibeus cinereus determine the southern and southwestern borders of their distributions, respectively (Gardner 2008, Tavares et al. 2008, Scultori et al. 2009). For Vampyressa pusilla, occurrences in Pantanal and in its bordering plateaus (Longo et al. 2007, Camargo et al. 2009) increase the species range northwesternward (Gardner 2008, Tavares et al. 2008). More significantly, records in Mato Grosso do Sul extends the distribution of Vampyrodes caraccioli to $1400 \mathrm{~km}$ southwesternward from Pará, $1250 \mathrm{~km}$ northwesternward from São Paulo coast, and $1060 \mathrm{~km}$ southeasternward from north Bolivia (Velazco et al. 2010b).

Likewise, the records in Mato Grosso do Sul mark the southwestern limit of distributions for Lionycteris spurrelli, Lonchorhina aurita, Lonchophylla mordax (Bordignon 2006), L. dekeyseri (Cunha et al. 2011), Micronycteris sanborni (Santos et al. 2010), Mimon crenulatum (Camargo \& Fischer 2005), Phyllostomus elongatus (Bordignon \& França 2009), Uroderma bilobatum (present study, Appendix 1), U. magnirostrum (Alho et al. 2011b; see Nogueira et al. 2003), 
Bats of Mato Grosso do Sul
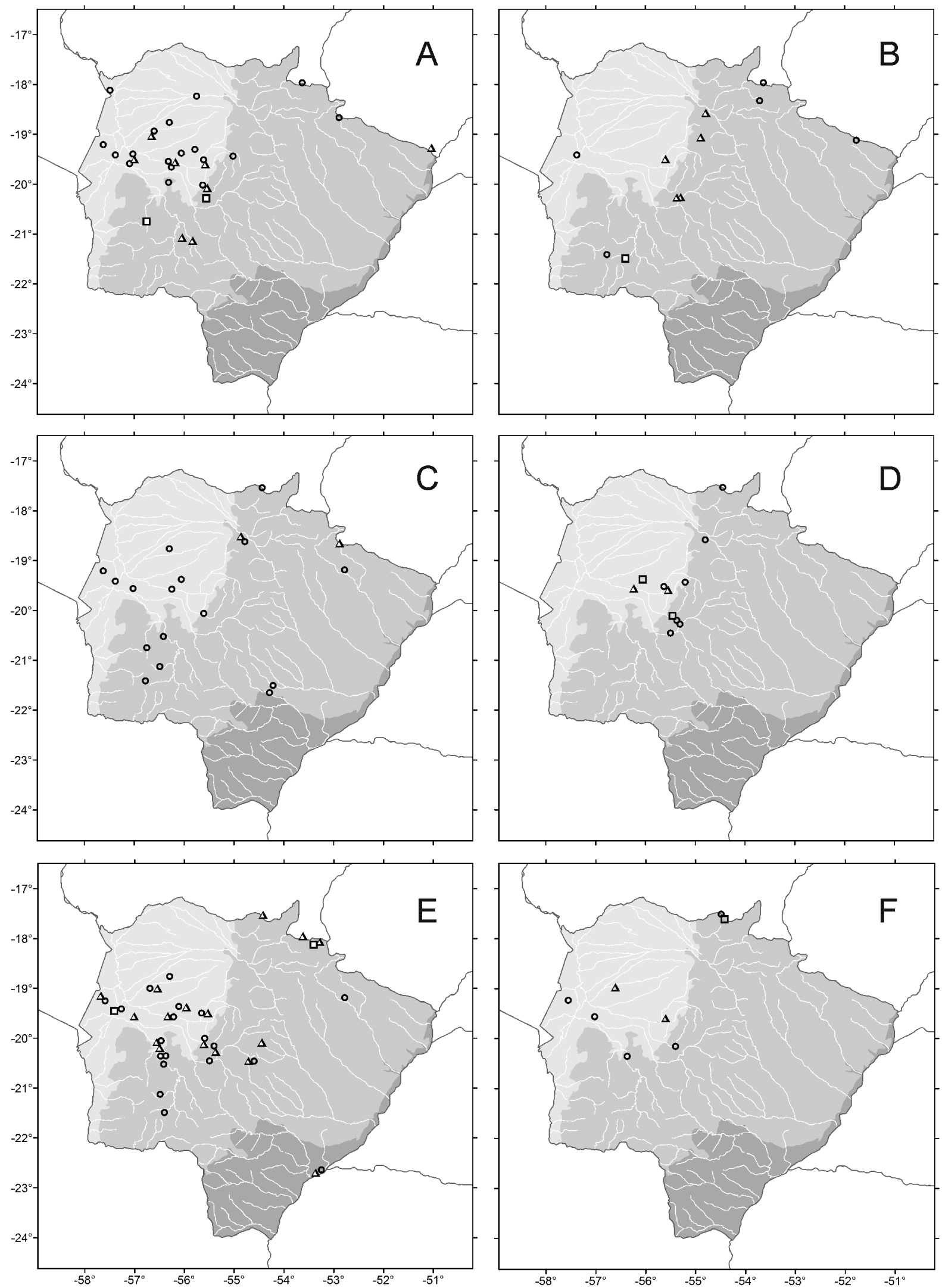

Figure 1. Distribution of Phyllostominae bats in the Pantanal (light grey), Cerrado (mid grey) and Mata Atlântica (dark grey) in Mato Grosso do Sul, Brazil. [A] Lophostoma brasiliense (triangle), L. silvicolum (circle), Macrophyllum macrophyllum (square); [B] Micronycteris sanborni (square), M. minuta (triangle), M. megalotis (circle); [C] Chrotopterus auritus (circle), Lonchorhina aurita (triangle); [D] Mimon bennettii (circle), M. crenulatum (triangle), Phylloderma stenops (square); [E] Phyllostomus elongatus (square), P. hastatus (circle), P. discolor (triangle); [F] Tonatia bidens (circle), Trachops cirrhosus (square), Vampyrum spectrum (triangle). 
Fischer, E. et al
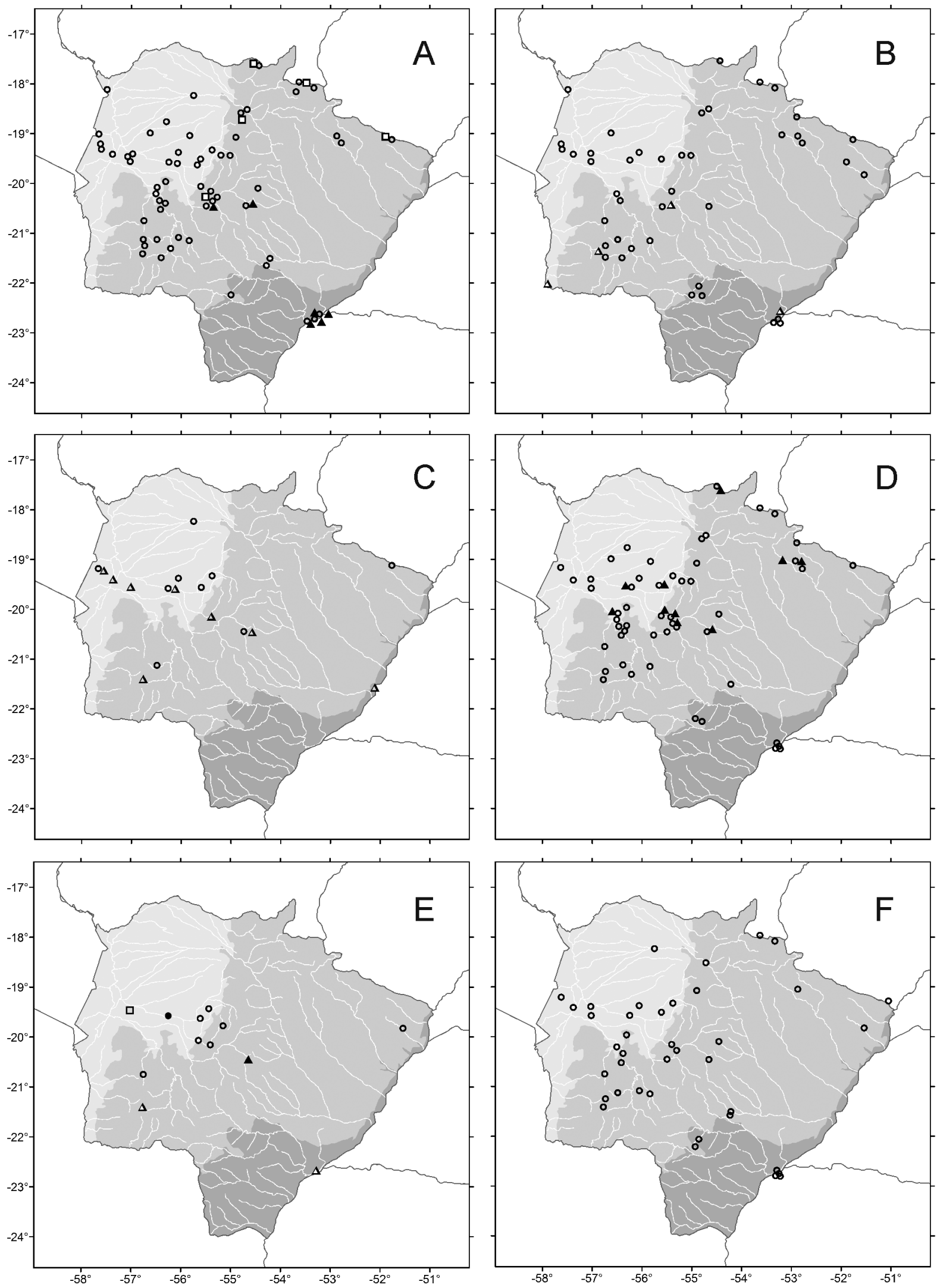

Figure 2. Distribution of Stenodermatinae bats in the Pantanal (light grey), Cerrado (mid grey) and Mata Atlântica (dark grey) in Mato Grosso do Sul, Brazil. [A] Artibeus cinereus (square), A. fimbriatus (filled triangle), A. planirostris (circle); [B] A. obscurus (triangle), A. lituratus (circle); [C] Chiroderma villosum (circle), C. doriae (triangle); [D] Platyrrhinus helleri (filled triangle), P. lineatus (circle); [E] Pygoderma bilabiatum (triangle), Uroderma bilobatum (filled circle), U. magnirostrum (filled triangle), Vampyressa pusilla (circle), Vampyrodes caraccioli (square); [F] Sturnira lilium. 
Bats of Mato Grosso do Sul
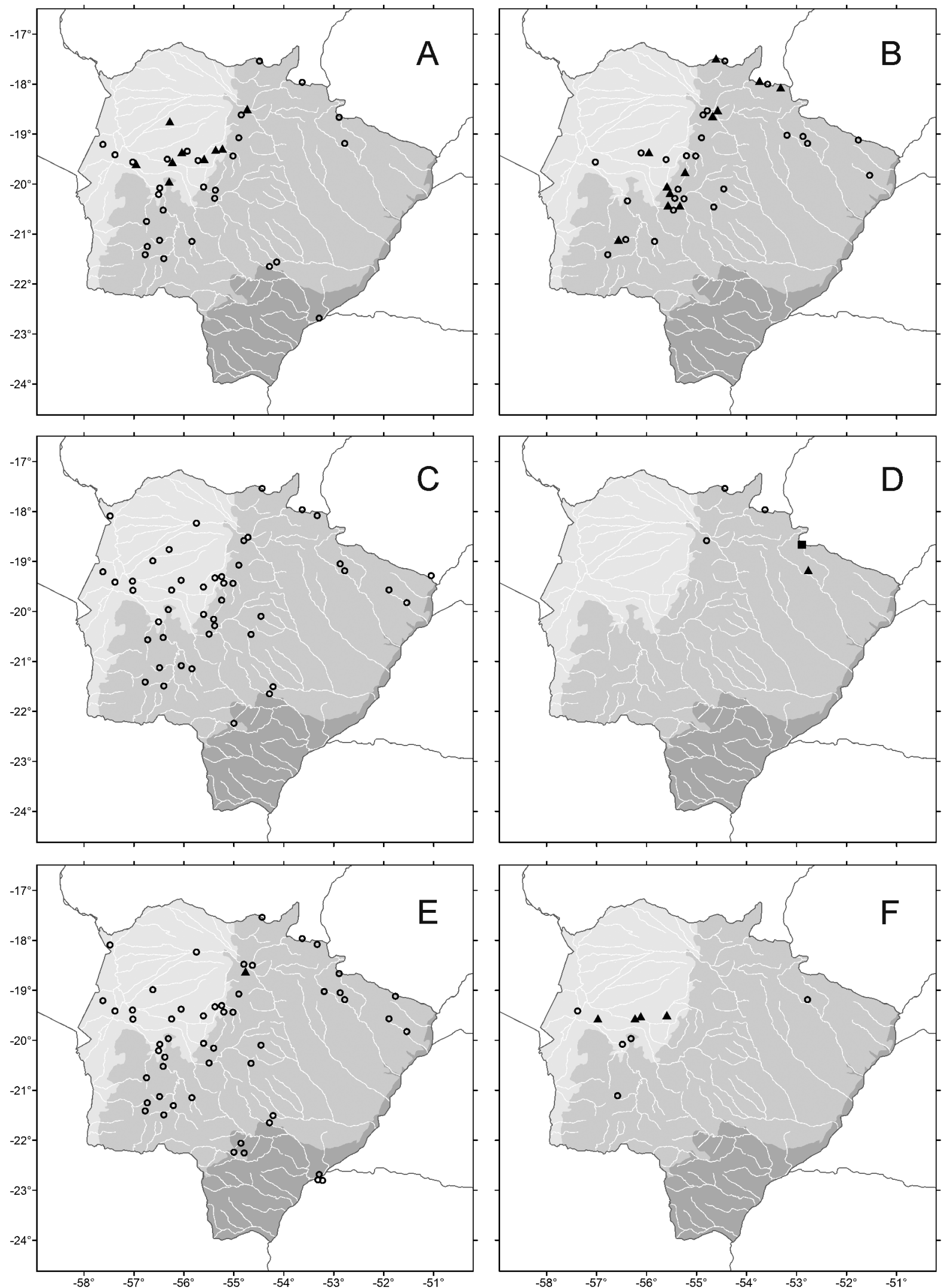

Figure 3. Distribution of Desmodontinae, Glossophaginae, Carolliinae and Emballonurinae bats in the Pantanal (light grey), Cerrado (mid grey) and Mata Atlântica (dark grey) in Mato Grosso do Sul, Brazil. [A] Desmodus rotundus (circle), Diaemus youngi (filled triangle); [B] Anoura geoffroyi (filled triangle), A. caudifer (circle); [C] Glossophaga soricina; [D] Lonchophylla dekeyseri (circle), L. mordax (filled triangle), Lionycteris spurrelli (filled square); [E] Carollia perspicillata (circle), Rhinophylla pumilio (filled triangle); [F] Peropteryx macrotis (circle), Rhynchonycteris naso (filled triangle). 
Fischer, E. et al
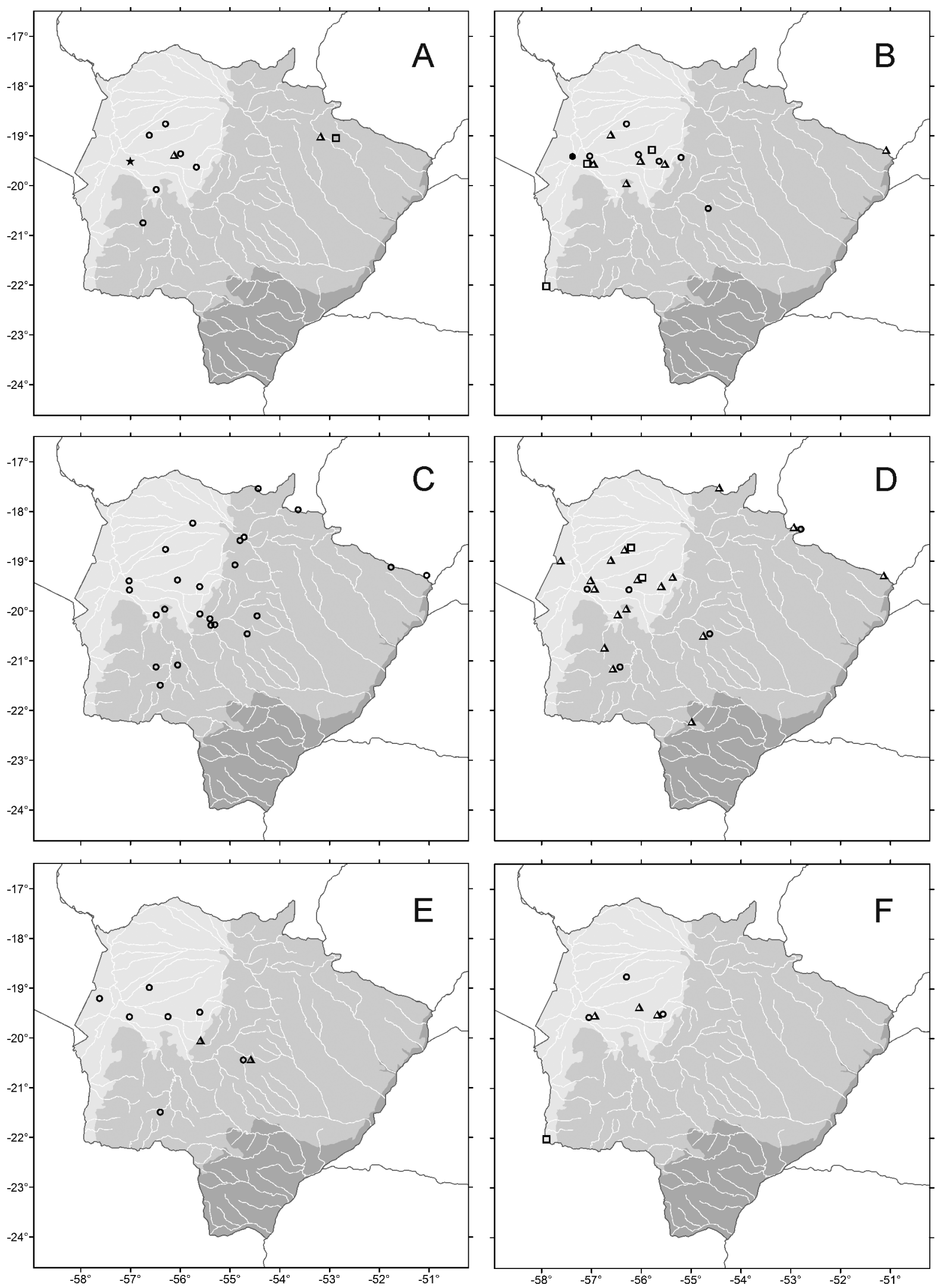

Figure 4. Distribution of Molossinae bats in the Pantanal (light grey), Cerrado (mid grey) and Mata Atlântica (dark grey) in Mato Grosso do Sul, Brazil. [A] Cynomops abrasus (circle), C. planirostris (triangle), Eumops dabbenei (star; first record in Brazil), Eumops bonariensis (square); [B] Eumops glaucinus (triangle), E. patagonicus (square), E. perotis (filled circle), E. auripendulus (circle); [C] Molossops temminckii; [D] Molossus rufus (circle), M. molossus (triangle), M. pretiosus (square); [E] Nyctinomops macrotis (triangle), N. laticaudatus (circle); [F] Promops centralis (circle), P. nasutus (triangle), Tadarida brasiliensis (square). 
Bats of Mato Grosso do Sul
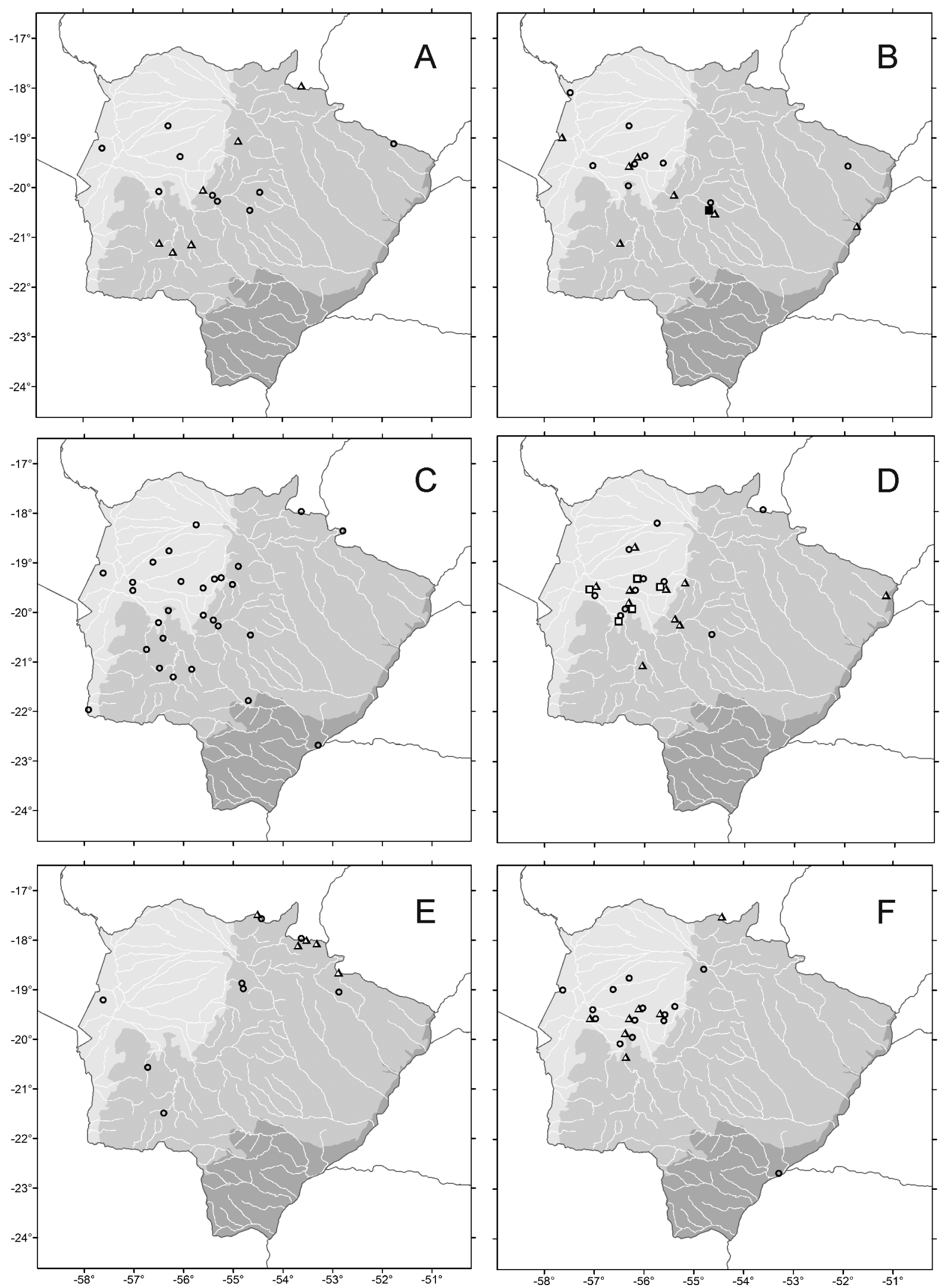

Figure 5. Distribution of Vespertilionidae, Mormoopidae, Natalidae and Noctilionidae bats in the Pantanal (light grey), Cerrado (mid grey) and Mata Atlântica (dark grey) in Mato Grosso do Sul, Brazil. [A] Eptesicus furinalis (circle), E. brasiliensis (triangle); [B] Lasiurus blossevillii (triangle), L. cinereus (filled square), L. ega (circle); [C] Myotis nigricans; [D] Myotis simus (square), M. riparius (triangle), M. albescens (circle); [E] Pteronotus parnellii (triangle), Natalus macrourus (circle); [F] Noctilio leporinus (triangle), N. albiventris (circle). 


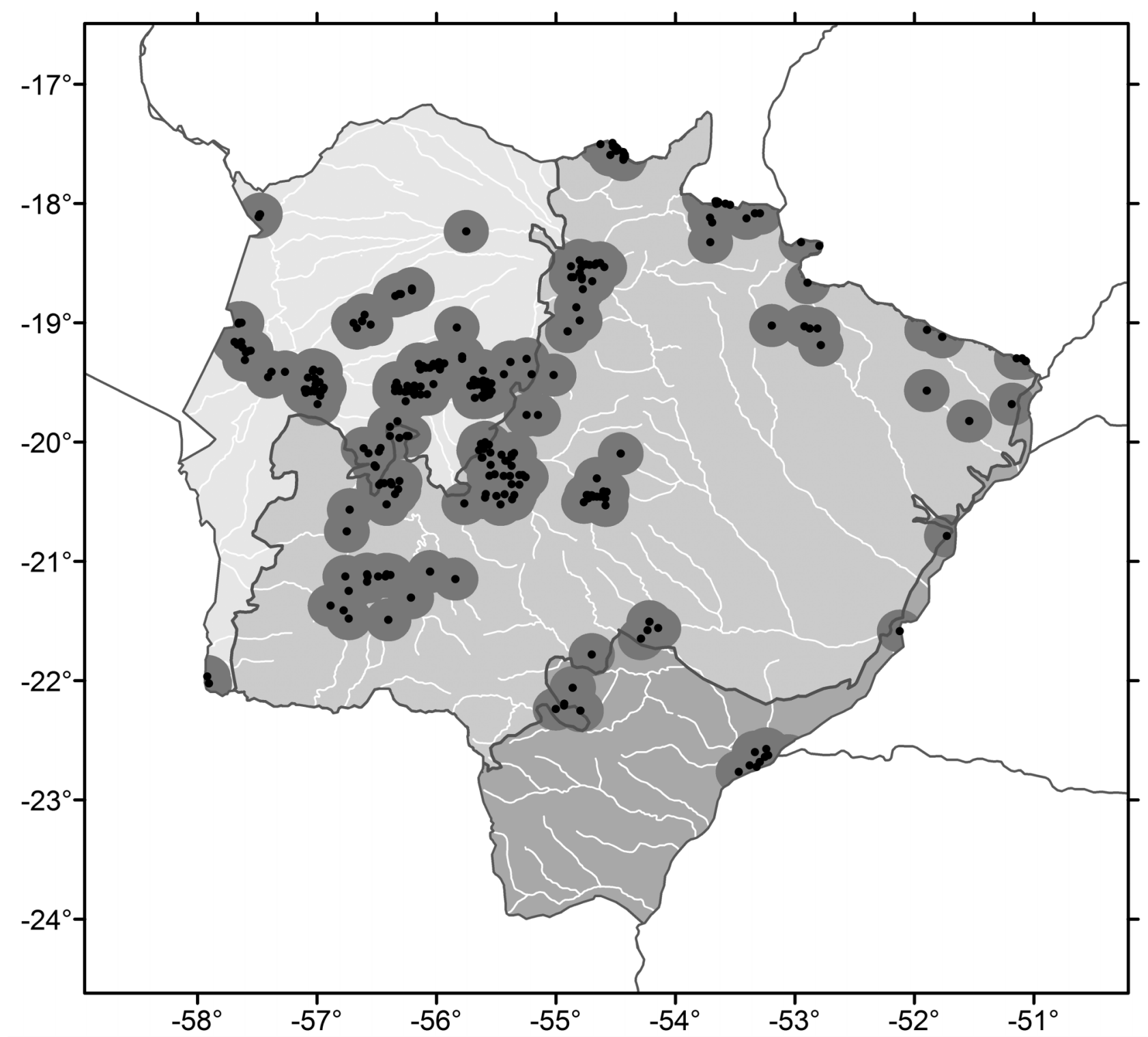

Figure 6. Distribution of sites of bat records (black dots) surrounded by a $20 \mathrm{~km}$ buffer zone (dark gray) in the state of Mato Grosso do Sul, Brazil. The total buffer areas account for $78,213 \mathrm{~km}^{2}$, which comprises $22 \%$ of the states' territory. Background gray tones indicate the domains Pantanal (light grey), Cerrado (mid grey) and Mata Atlântica (dark grey).

Rhinophylla pumilio (Coelho 2005; see Rinehart \& Kunz 2006), and Rhynchonycteris naso (Camargo 2003; present study, Appendix 1). For Eumops patagonicus, records in this state extend its geographical distribution northeasternward (Gardner 2008, Bordignon et al. 2011, Waideman et al. 2011; present study, Appendix 1). In addition, occurrences in Mato Grosso do Sul are the southern edges of distribution for Molossus pretiosus and Pteronotus parnellii; records also support that M. pretiosus likely occurs widely in the Pantanal (see Gregorin \& Taddei 2000). Occurrences of Promops centralis in Mato Grosso do Sul are the first ones in Brazil out of Amazon, and they establish a new species' southeastern limit of distribution (Nogueira \& Peracchi 1999, Alho et al. 2011b; present study, Appendix 1). Overall, sites in Mato Grosso do Sul represent the limits of distribution for at least 22 species of bats, 17 Phyllostomidae (eight Phyllostominae, five Stenodermatinae, three Glossophaginae, and one Carolliinae), three Molossidae, one Emballonuridae, and one
Mormoopidae. Most of these records have not yet been considered in reviews of South American bat distributions (e.g. Gardner 2008).

\section{Concluding remarks}

The chiropteran fauna of Mato Grosso do Sul is highly diverse, and the number of species will likely increase through new inventories across vast areas still unknown regarding to bat occurrences. In addition, as the present data were mostly collected through netting or documentation in roosts, new samplings by records of echolocation calls will probably improve the knowledge on species which roost in less accessible places and are uncommonly mist-netted (Barnett et al. 2006). The general distribution of bat surveyed sites is biased toward the midwestern portion of the Mato Grosso do Sul's territory (Figure 6), in the regions of Miranda and Negro basins, which include part of the Pantanal and Cerrado plateaus, named 
Serra da Bodoquena and Serra de Maracaju. Such distribution is likely related to the accessibility via roads, markedly from the capital Campo Grande to Corumbá, Coxim, and towns in the Bodoquena region. In the opposite direction, our compilation also supports that the vast eastern Mato Grosso do Sul is largely unknown about bat occurrences, except by the extreme northeastern (Figure 6). This wide gap comprises all sub-basins of the Paraná river throughout the Cerrado and Atlantic Forest areas in Mato Grosso do Sul. Other relevant gaps of bat surveys are the northwestern Pantanal in the Taquari basin, and the southwestern Pantanal close to the Chaco and to the southern Brazilian Cerrado. In a roughly estimation, discounting a $20 \mathrm{~km}$ buffer zone around sites of bat records, $78 \%$ of the state's territory is still uncovered for bat occurrences (Figure 6). Unsurvey areas per domain reach 91\% in Atlantic forest, 78\% in Cerrado, and $71 \%$ in Pantanal. Furthermore, the expectation of species increment is not only based on large gap areas. As we included records conservatively, future corrections on the present checklist are prone to add rather than to subtract species. A general relevant issue is that Mato Grosso do Sul comprises a major ecotonal zone in South America. It likely explains the occurrence of species at edges of their distributions, as evidenced by numerous species of bats whose northern, southern, eastern or western geographical limits are in Mato Grosso do Sul; like Eumops dabbenei for instance.

\section{Appendix 1. Sources of records included in the distribution maps of bat species, in alphabetical order, in the Mato Grosso do Sul state, Brazil.}

Anoura caudifer - LITERATURE: Pulchério-Leite et al. 1998, Camargo 2003, Coelho 2005, Bordignon 2006, Fernandes 2009, Longo 2009, Ferreira et al. 2010, Alho et al. 2011, Cunha et al. 2011, Eriksson et al. 2011; UNPUBLISHED RECORDS: Nicolay Cunha (19 $\left.07^{\circ} \mathrm{S}, 51^{\circ} 45^{\prime} \mathrm{W}\right)$.

Anoura geoffroyi - LITERATURE: Pulchério-Leite et al. 1998, Coelho 2005, Alho et al. 2011, Cunha et al. 2011; MUSEUM: ZUFMS (0151, 0368, 0454).

Artibeus cinereus - LITERATURE: Coelho 2005, Cunha et al. 2011; MUSEUM: ZUFMS (0360); UNPUBLISHED RECORDS: Nicolay Cunha $\left(19^{\circ} 07^{\prime} \mathrm{S}, 51^{\circ} 45^{\prime} \mathrm{W}\right)$.

Artibeus fimbriatus - LITERATURE: Deus et al. 2003, Cáceres et al. 2008, Ortêncio-Filho et al. 2010, Zanon 2010.

Artibeus lituratus - LITERATURE: Coelho 2005, Bordignon 2006, Bordignon \& França 2009, Camargo et al. 2009, Cunha et al. 2009, Fernandes 2009, Longo 2009, Teixeira et al. 2009, Ferreira et al. 2010, Ortêncio-Filho et al. 2010, Zanon 2010, Alho et al. 2011, Cunha et al. 2011, Eriksson et al. 2011, Gonçalves et al. 2012, Munin et al. 2012; MUSEUM: ZUFMS (0577); UNPUBLISHED RECORDS: Luiz F Carvalho, Nicolay Cunha, Carolina F Santos (18 $06^{\prime}$ S, $57^{\circ} 29^{\prime} \mathrm{W}$; $19^{\circ} 12^{\prime} \mathrm{S}, 57^{\circ} 37^{\prime} \mathrm{W}$ ); Nayara F Carvalho (22 ${ }^{\circ} 14^{\prime} \mathrm{S}, 54^{\circ} 59^{\prime} \mathrm{W}$; $22^{\circ} 15^{\prime} \mathrm{S}, 54^{\circ} 47^{\prime} \mathrm{W}$; $\left.22^{\circ} 03^{\prime} \mathrm{S}, 54^{\circ} 51^{\prime} \mathrm{W}\right)$; Nicolay Cunha $\left(19^{\circ} 07^{\prime} \mathrm{S}, 51^{\circ} 45^{\prime} \mathrm{W}\right)$.

Artibeus obscurus - LITERATURE: Fernandes 2009, Bordignon \& Santos 2010, Zanon 2010, Eriksson et al. 2011.

Artibeus planirostris - LITERATURE: Coelho 2005, Bordignon 2006, Bordignon \& França 2009, Camargo et al. 2009, Cunha et al. 2009, Fernandes 2009, Longo 2009, Teixeira et al. 2009, Ferreira et al. 2010, Ortêncio-Filho et al. 2010, Zanon 2010, Alho et al. 2011, Cunha et al. 2011,
Eriksson et al. 2011, Silveira 2011, Munin et al. 2012; MUSEUM: ZUFMS (0382, 0466, 0471, 0578); UNPUBLISHED RECORDS: Luiz F Carvalho, Nicolay Cunha,

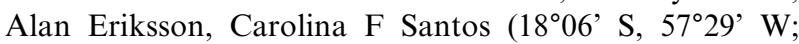

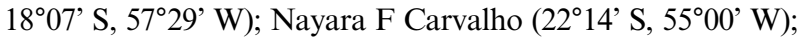
Nicolay Cunha $\left(19^{\circ} 07^{\prime} \mathrm{S}, 51^{\circ} 46^{\prime} \mathrm{W} ; 21^{\circ} 39^{\prime} \mathrm{S}, 54^{\circ} 17^{\prime} \mathrm{W}\right.$; $21^{\circ} 35^{\prime} \mathrm{S}, 54^{\circ} 14^{\prime} \mathrm{W} ; 21^{\circ} 36^{\prime} \mathrm{S}, 54^{\circ} 14^{\prime} \mathrm{W} ; 21^{\circ} 30^{\prime} \mathrm{S}, 54^{\circ} 13^{\prime} \mathrm{W}$; $\left.19^{\circ} 13^{\prime} \mathrm{S}, 57^{\circ} 37^{\prime} \mathrm{W}\right)$.

Carollia perspicillata - LITERATURE: Pulchério-Leite et al. 1998, Coelho 2005, Bordignon 2006, Bordignon \& França 2009, Camargo et al. 2009, Cunha et al. 2009, Fernandes 2009, Longo 2009, Teixeira et al. 2009, Ferreira et al. 2010, Ortêncio-Filho et al. 2010, Zanon 2010, Alho et al. 2011, Cunha et al. 2011, Eriksson et al. 2011, Munin et al. 2012; MUSEUM: ZUFMS (0179, 0371, 0372); UNPUBLISHED RECORDS: Luiz F Carvalho, Nicolay Cunha, Alan Eriksson, Carolina F Santos $\left(18^{\circ} 06^{\prime} \mathrm{S}, 5^{\circ} 29^{\prime} \mathrm{W} ; 1^{\circ} 13^{\prime}\right.$

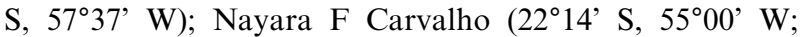

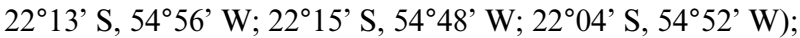
Nicolay Cunha $\left(19^{\circ} 07^{\prime} \mathrm{S}, 51^{\circ} 46^{\prime} \mathrm{W} ; 21^{\circ} 39^{\prime} \mathrm{S}, 54^{\circ} 17^{\prime} \mathrm{W}\right.$; $21^{\circ} 34^{\prime} \mathrm{S}, 54^{\circ} 15^{\prime} \mathrm{W} ; 21^{\circ} 35^{\prime} \mathrm{S}, 54^{\circ} 14^{\prime} \mathrm{W}$; $21^{\circ} 36^{\prime} \mathrm{S}, 54^{\circ} 14^{\prime} \mathrm{W}$; $21^{\circ} 30^{\prime} \mathrm{S}, 54^{\circ} 13^{\prime} \mathrm{W}$ ).

Chiroderma doriae - LITERATURE: Gregorin 1998, Bordignon \& França 2009, Ferreira et al. 2010, Alho et al. 2011, Eriksson et al. 2011, Munin et al. 2012; MUSEUM: ZUFMS (0258); UNPUBLISHED RECORDS: Luiz F Carvalho, Nicolay Cunha, Carolina F Santos $\left(19^{\circ} 13^{\prime} \mathrm{S}\right.$, $\left.57^{\circ} 37^{\prime} \mathrm{W}\right)$; Alan Eriksson (19 $\left.34^{\prime} \mathrm{S}, 5^{\circ} 01^{\prime} \mathrm{W}\right)$.

Chiroderma villosum - LITERATURE: Pulchério-Leite et al. 1998, Ferreira et al. 2010, Alho et al. 2011; ZUFMS (0158, 0159, 0208, 0209, 0505); UNPUBLISHED RECORDS: Nicolay Cunha (1907' S, 51 $\left.46^{\prime} \mathrm{W}\right)$.

Chrotopterus auritus - LITERATURE: Coelho 2005, Bordignon 2006, Bordignon \& França 2009, Camargo et al. 2009, Alho et al. 2011, Cunha et al. 2011, Eriksson et al. 2011, Munin et al. 2012; MUSEUM: ZUFMS (0109, 0354); UNPUBLISHED RECORDS: Luiz F Carvalho, Nicolay Cunha, Carolina F Santos $\left(19^{\circ} 13^{\prime}\right.$ S, $\left.57^{\circ} 37^{\prime} \mathrm{W}\right)$; Nicolay

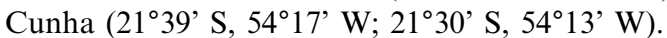

Cynomops abrasus - LITERATURE: Pulchério-Leite et al. 1998, Camargo et al. 2009, Alho et al. 2011, Silveira 2011; MUSEUM: ZUFMS (0377).

Cynomops planirostris - LITERATURE: Pulchério-Leite et al. 1998, Bordignon 2006; MUSEUM: ZUFMS (0162).

Desmodus rotundus - LITERATURE: Pulchério-Leite et al. 1998, Coelho 2005, Bordignon 2006, Bordignon \& França 2009, Camargo et al. 2009, Cunha et al. 2009, Longo 2009, Zanon 2010, Alho et al. 2011, Cunha et al. 2011, Eriksson et al. 2011, Munin et al. 2012; MUSEUM: ZUFMS (0115, 0121, 0340, 0364); UNPUBLISHED RECORDS: Luiz F Carvalho, Nicolay Cunha, Carolina F Santos $\left(19^{\circ} 13^{\prime} \mathrm{S}\right.$, $\left.57^{\circ} 37^{\prime} \mathrm{W}\right)$; Nicolay Cunha $\left(21^{\circ} 39^{\prime} \mathrm{S}, 54^{\circ} 17^{\prime} \mathrm{W} ; 21^{\circ} 35^{\prime} \mathrm{S}\right.$, $\left.54^{\circ} 14^{\prime} \mathrm{W}\right)$.

Diaemus youngi - LITERATURE: Pulchério-Leite et al. 1998, Alho et al. 2011, Munin et al. 2012; MUSEUM: ZUECMAM (384, 385), ZUFMS (0078, 0164, 0165).

Eptesicus brasiliensis - LITERATURE: Coelho 2005, Cáceres et al. 2007, Longo 2009; MUSEUM: ZUFMS (0160).

Eptesicus furinalis - LITERATURE: Pulchério-Leite et al. 1998, Alho et al. 2011; UNPUBLISHED RECORDS: Luiz F Carvalho, Nicolay Cunha, Carolina F Santos $\left(19^{\circ} 07^{\prime} \mathrm{S}\right.$, $51^{\circ} 46^{\prime} \mathrm{W}$; $\left.19^{\circ} 13^{\prime} \mathrm{S}, 57^{\circ} 37^{\prime} \mathrm{W}\right)$. 
Eumops auripendulus - LITERATURE: Alho et al. 2011; ZUFMS (0146).

Eumops bonariensis - LITERATURE: Bordignon 2006.

Eumops dabbenei - MUSEUM: ZUFMS (1319).

Eumops glaucinus - LITERATURE: Camargo 2003, Bordignon 2006, Alho et al. 2011; MUSEUM: ZUFMS (0145, 0298).

Eumops patagonicus - LITERATURE: Bordignon et al. 2011, Waideman et al. 2011; MUSEUM: ZUFMS (0470).

Eumops perotis - LITERATURE: Bordignon \& França 2009; MUSEUM: ZUFMS (0045).

Glossophaga soricina - LITERATURE: Pulchério-Leite et al. 1998, Coelho 2005, Bordignon 2006, Bordignon \& França 2009, Cunha et al. 2009, Fernandes 2009, Longo 2009, Ferreira et al. 2010, Alho et al. 2011, Cunha et al. 2011, Eriksson et al. 2011, Munin et al. 2012; MUSEUM: ZUFMS (0283, 0344, 0366, 0367, 0369); UNPUBLISHED RECORDS: Luiz F Carvalho, Nicolay Cunha, Carolina F Santos $\left(19^{\circ} 13^{\prime} \mathrm{S}, 57^{\circ} 37^{\prime} \mathrm{W}\right)$; Nayara F Carvalho (22 ${ }^{\circ} 14^{\prime} \mathrm{S}$, $\left.55^{\circ} 00^{\prime} \mathrm{W}\right)$; Nicolay Cunha (19 $07^{\prime} \mathrm{S}, 51^{\circ} 46^{\prime} \mathrm{W} ; 21^{\circ} 39^{\prime} \mathrm{S}$, $\left.54^{\circ} 17^{\prime} \mathrm{W} ; 21^{\circ} 35^{\prime} \mathrm{S}, 54^{\circ} 14^{\prime} \mathrm{W} ; 21^{\circ} 30^{\prime} \mathrm{S}, 54^{\circ} 13^{\prime} \mathrm{W}\right)$; Erich Fischer, Paulo R Souza ( $18^{\circ} 05^{\prime}$ S, $\left.57^{\circ} 29^{\prime} \mathrm{W}\right)$.

Lasiurus blossevillii - LITERATURE: Pulchério-Leite et al. 1998, Alho et al. 2011; MUSEUM: ZUEC-MAM (2632), ZUFMS (0134, 0135, 0171, 0252); UNPUBLISHED

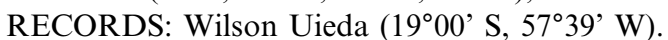

Lasiurus cinereus - LITERATURE: Alho et al. 2011.

Lasiurus ega - LITERATURE: Pulchério-Leite et al. 1998, Camargo 2003, Bordignon 2006, Alho et al. 2011, Oliveira et al. 2011; MUSEUM: ZUFMS (0138, 0176, 0253).

Lionycteris spurrelli - LITERATURE: Bordignon 2006.

Lonchophylla dekeyseri - LITERATURE: Coelho 2005, Cunha et al. 2011.

Lonchophylla mordax - LITERATURE: Bordignon 2006.

Lonchorhina aurita - LITERATURE: Coelho 2005, Bordignon 2006.

Lophostoma brasiliense - LITERATURE: Bordignon 2006, Longo 2009, Alho et al. 2011, Silveira 2011, Munin et al. 2012; MUSEUM: ZUFMS (0113, 0318, 0357).

Lophostoma silvicolum - LITERATURE: Pulchério-Leite et al. 1998, Coelho 2005, Bordignon 2006, Bordignon \& França 2009, Longo 2009, Alho et al. 2011, Silveira 2011, Munin et al. 2012; MUSEUM: ZUFMS (0110, 0181, 0356); UNPUBLISHED RECORDS: Luiz F Carvalho, Nicolay Cunha,

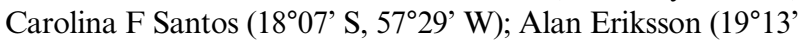
$\left.\mathrm{S}, 57^{\circ} 37^{\prime} \mathrm{W}\right)$.

Macrophyllum macrophyllum - LITERATURE: Camargo et al. 2009; MUSEUM: ZUFMS (0072).

Micronycteris megalotis - LITERATURE: Coelho 2005, Bordignon \& França 2009, Eriksson et al. 2011; ZUFMS (0347); UNPUBLISHED RECORDS: Nicolay Cunha (1907' $\left.\mathrm{S}, 51^{\circ} 46^{\prime} \mathrm{W}\right)$.

Micronycteris minuta - LITERATURE: Pulchério-Leite et al. 1998, Coelho 2005, Longo 2009, Alho et al. 2011.

Micronycteris sanborni - LITERATURE: Santos et al. 2010.

Mimon bennettii - LITERATURE: Coelho 2005, Fernandes 2009, Alho et al. 2011, Oliveira et al. 2011; UNPUBLISHED RECORDS: Nicolay Cunha ( $\left.17^{\circ} 32^{\prime} \mathrm{S}, 54^{\circ} 27^{\prime} \mathrm{W}\right)$.

Mimon crenulatum - LITERATURE: Camargo \& Fischer 2005; MUSEUM: ZUFMS (0108).

Molossops temminckii - LITERATURE: Pulchério-Leite et al. 1998, Coelho 2005, Bordignon 2006, Cunha et al. 2009, Longo 2009, Ferreira et al. 2010, Alho et al. 2011, Cunha et al. 2011; MUSEUM: ZUFMS (0147); UNPUBLISHED RECORDS: Nicolay Cunha (1907' S, 51 $\left.{ }^{\circ} 46^{\prime} \mathrm{W}\right)$.

Molossus molossus - LITERATURE: Bordignon 2006, Camargo et al. 2009, Longo 2009, Alho et al. 2011; MUSEUM: ZUFMS (0271); UNPUBLISHED

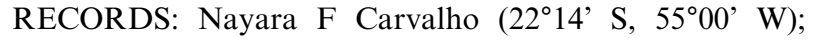
Nicolay Cunha $\left(17^{\circ} 32^{\prime} \mathrm{S}, 54^{\circ} 27^{\prime} \mathrm{W}\right)$; Wilson Uieda $\left(19^{\circ} 00^{\prime}\right.$ $\left.\mathrm{S}, 57^{\circ} 38^{\prime} \mathrm{W}\right)$.

Molossus pretiosus - LITERATURE: Alho et al. 2011.

Molossus rufus - LITERATURE: Camargo 2003, Bordignon 2006, Alho et al. 2011; UNPUBLISHED RECORDS: George Camargo, Carolina F Santos (19³4' S, 56 $15^{\prime}$ W).

Myotis albescens - LITERATURE: Coelho 2005, Alho et al. 2011; MUSEUM: ZUFMS (0141, 0170); UNPUBLISHED RECORDS: George Camargo, Carolina F Santos (19³4’ S, $\left.56^{\circ} 15^{\prime} \mathrm{W}\right)$.

Myotis nigricans - LITERATURE: Coelho 2005, Bordignon 2006, Camargo et al. 2009, Longo 2009, Ferreira et al. 2010, Zanon 2010, Alho et al. 2011, Moratelli et al. 2011; MUSEUM: ZUFMS (0133, 0137, 0172, 0175, 0203, 0204, 0283, 0378, 0379, 0381); UNPUBLISHED RECORDS: Luiz F Carvalho, Nicolay Cunha, Carolina F Santos (19¹3' S, 57 $\left.37^{\prime} \mathrm{W}\right)$.

Myotis riparius - LITERATURE: Camargo 2003, Alho et al. 2011, Moratelli et al. 2011; MUSEUM: ZUFMS (0140).

Myotis simus - LITERATURE: Alho et al. 2011, Moratelli et al. 2011; MUSEUM: ZUFMS (0006).

Natalus macrourus - LITERATURE: Taddei \& Uieda 2001, Coelho 2005, Bordignon 2006, Cunha et al. 2009, 2011; MUSEUM: ZUFMS (0329, 0330, 0331).

Noctilio albiventris - LITERATURE: Pulchério-Leite et al. 1998, Coelho 2005, Gonçalves et al. 2007, Longo 2009, Zanon 2010, Alho et al. 2011; MUSEUM: ZUFMS (0365); UNPUBLISHED RECORDS: Wilson Uieda (1900' $\mathrm{S}$, $57^{\circ} 38^{\prime} \mathrm{W}$ ).

Noctilio leporinus - LITERATURE: Alho et al. 2011; MUSEUM: ZUFMS (0143); UNPUBLISHED

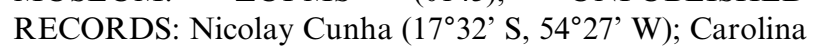
F Santos (19 $\left.34^{\prime} \mathrm{S}, 56^{\circ} 15^{\prime} \mathrm{W}\right)$.

Nyctinomops laticaudatus - LITERATURE: Cunha et al. 2009, Alho et al. 2011; MUSEUM: ZUFMS (0008, 0012, 0018, 0149, 0305, 0306, 0478); UNPUBLISHED RECORDS: Luiz F Carvalho, Nicolay Cunha, Carolina F Santos (19³4' S, $\left.56^{\circ} 15^{\prime} \mathrm{W}\right)$.

Nyctinomops macrotis - LITERATURE: Alho et al. 2011; MUSEUM: ZUFMS (0148).

Peropteryx macrotis - LITERATURE: Bordignon 2005, 2006, Labruna \& Venzal 2009, Alho et al. 2011.

Phylloderma stenops - LITERATURE: Pulchério-Leite et al. 1998, Alho et al. 2011.

Phyllostomus discolor - LITERATURE: Pulchério-Leite et al. 1998, Coelho 2005, Longo 2009, Ferreira et al. 2010, Zanon 2010, Alho et al. 2011, Cunha et al. 2011, Munin et al. 2012; MUSEUM: ZUFMS (0105, 0155, 0355, 0468).

Phyllostomus elongatus - LITERATURE: Coelho 2005, Bordignon \& França 2009.

Phyllostomus hastatus - LITERATURE: Bordignon 2006, Bordignon \& França 2009, Cunha et al. 2009, Fernandes 2009, Ferreira et al. 2010, Zanon 2010, Alho et al. 2011, Munin et al. 2012; MUSEUM: ZUFMS (0106, 0352, 0353); UNPUBLISHED RECORDS: Luiz F Carvalho, Nicolay Cunha, Carolina F Santos (19 $13^{\prime}$ S, $\left.57^{\circ} 37^{\prime} \mathrm{W}\right)$. 
Platyrrhinus helleri - LITERATURE: Bordignon 2006, Ferreira et al. 2010, Alho et al. 2011, Cunha et al. 2011, Munin et al. 2012; MUSEUM: ZUFMS (0158, 0361); UNPUBLISHED

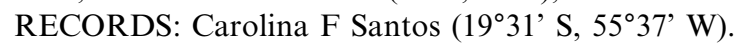

Platyrrhinus lineatus - LITERATURE: Pulchério-Leite et al. 1998, Coelho 2005, Bordignon 2006, Bordignon \& França 2009, Camargo et al. 2009, Fernandes 2009, Longo 2009, Teixeira et al. 2009, Ferreira et al. 2010, Ortêncio-Filho et al. 2010, Zanon 2010, Alho et al. 2011, Cunha et al. 2011, Eriksson et al. 2011, Munin et al. 2011, 2012; MUSEUM: ZUFMS (0210, 0211, 0212, 0266, 0349, 0370); UNPUBLISHED RECORDS: Nayara F Carvalho (22 ${ }^{\circ} 15^{\prime}$ S, $54^{\circ} 48^{\prime} \mathrm{W}$;

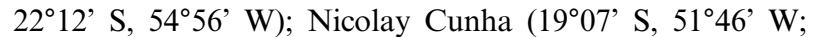

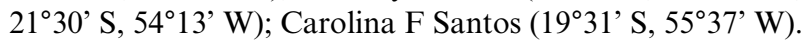

Promops centralis - LITERATURE: Alho et al. 2011; ZUFMS (0021).

Promops nasutus - LITERATURE: Alho et al. 2011; ZUFMS (0039).

Pteronotus parnellii - LITERATURE: Coelho 2005, Bordignon 2006, Cunha et al. 2011; MUSEUM: ZUFMS (0232).

Pygoderma bilabiatum - LITERATURE: Zanon 2010, Eriksson et al. 2011.

Rhinophylla pumilio - LITERATURE: Coelho 2005.

Rhynchonycteris naso - LITERATURE: Camargo 2003; MUSEUM: ZUFMS (0234, 0260, 0261); UNPUBLISHED RECORDS: Nicolay Cunha $\left(19^{\circ} 35^{\prime} \mathrm{S}, 56^{\circ} 15^{\prime} \mathrm{W}\right)$; Alan Eriksson $\left(19^{\circ} 32^{\prime} \mathrm{S}, 56^{\circ} 08^{\prime} \mathrm{W}\right)$.

Sturnira lilium - LITERATURE: Pulchério-Leite et al. 1998, Coelho 2005, Bordignon 2006, Bordignon \& França 2009, Camargo et al. 2009, Fernandes 2009, Longo 2009, Teixeira et al. 2009, Ferreira et al. 2010, Ortêncio-Filho et al. 2010, Zanon 2010, Alho et al. 2011, Eriksson et al. 2011, Oliveira et al. 2011, Munin et al. 2012; UNPUBLISHED RECORDS: Luiz F Carvalho, Nicolay Cunha, Carolina F Santos $\left(19^{\circ} 13^{\prime}\right.$ S, 57 $37^{\prime}$ W); Nayara F Carvalho (22 $13^{\prime} \mathrm{S}, 54^{\circ} 56^{\prime} \mathrm{W}$; $\left.22^{\circ} 04^{\prime} \mathrm{S}, 54^{\circ} 52^{\prime} \mathrm{W}\right)$; Nicolay Cunha ( $21^{\circ} 35^{\prime} \mathrm{S}, 54^{\circ} 14^{\prime} \mathrm{W}$; $21^{\circ} 30^{\prime} \mathrm{S}$ e $\left.54^{\circ} 13^{\prime} \mathrm{W}\right)$.

Tadarida brasiliensis - LITERATURE: Santos \& Bordignon 2011.

Tonatia bidens - LITERATURE: Williams et al. 1995, Camargo 2003, Alho et al. 2011, Cunha et al. 2011.

Trachops cirrhosus - LITERATURE: Cunha et al. 2011.

Uroderma bilobatum - MUSEUM: ZUFMS (0132).

Uroderma magnirostrum - LITERATURE: Alho et al. 2011.

Vampyressa pusilla - LITERATURE: Bordignon 2006, Longo et al. 2007, Camargo et al. 2009, Alho et al. 2011; MUSEUM: ZUFMS (0356).

Vampyrodes caraccioli - MUSEUM: ZUFMS (0129).

Vampyrum spectrum - LITERATURE: Silveira et al. 2011.

\section{Acknowledgements}

To Alan Eriksson, Fernando Gonçalves, Gustavo Graciolli, José Milton Longo, Nayara Fonseca de Carvalho, Paulo Robson de Souza, Roberto Munin, and Wilson Uieda for sharing their knowledge with us; to Gustavo Graciolli for review of early versions; to CAPES, CNPq, Conservação Internacional, Earthwatch Institute, and FUNDECT for funds and grants which have supported most studies on bats in Mato Grosso do Sul. We dedicate this study to the memories of Luiz Onofre Irineu de Souza and Valdir Antônio Taddei, precursors of the knowledge on bats of Mato Grosso do Sul.

\section{References}

AB'SABER, A.N. 2000.The natural organization of Brazilian inter and subtropical landscapes. Revista do Instituto Geológico 21:57-70.

AGUIRRE, L.F. 2007. Historia natural, distribución y conservación de los murciélagos de Bolívia. Centro de Ecología y Difusión Simón, Santa Cruz.

ALHO, C.J.R., CAMARGO, G. \& FISCHER, E. 2011a. Terrestrial and aquatic mammals of the Pantanal. Braz. J. Biol. 71:297-310.

ALHO, C.J.R., FISCHER, E., OLIVEIRA-PISSINI, L.F. \& SANTOS, C.F. 2011b. Bat-species richness in the Pantanal floodplain and its surrounding uplands. Braz. J. Biol. 71:311-320.

BARNETT, A.A., SAMPAIO, E.M., KALKO, E.K.V., SHAPLEY, R.L., FISCHER, E., CAMARGO, G. \& RODRÍGUEZ-HERRERA, B. 2006. Bats of Jaú National Park, central Amazônia, Brazil. Acta Chirop. 8:103-128.

BARQUEZ, R.M., MARES, M.A. \& BRAUN, J.K. 1999. The bats of Argentina. The Museum of Texas Tech University, Lubbock. Special Publications 42:1-273.

BERNARD, E., AGUIAR, L.M.S. \& MACHADO, R.B. 2011. Discovering the Brazilian bat fauna: a task for two centuries? Mammal Rev. 41:23-39.

BERNARDI, I.P., PULCHÉRIO-LEITE, A., MIRANDA, J.M.D. \& PASSOS, F.C. 2007. Ampliação da distribuição de Molossops neglectus Williams \& Genoways (Chiroptera, Molossidae) para o sul da América do Sul. Rev. Bras. Zool. 24:505-507.

BIANCONI, G.V. \& PEDRO, W.A. 2007. Família Vespertilionidae. In Morcegos do Brasil (N.R. Reis, A.L. Peracchi, W.A. Pedro, I.P. Lima, eds.). Londrina, Paraná, p.167-195.

BORDIGNON, M.O. 2005. Predação de morcegos por Chrotopterus auritus (Peters) (Mammalia, Chiroptera) no Pantanal de Mato Grosso do Sul, Brasil. Rev. Brasil. Zool. 22:1207-1208.

BORDIGNON, M.O. 2006. Diversidade de morcegos (Mammalia, Chiroptera) do Complexo Aporé-Sucuriú, Mato Grosso do Sul, Brasil. Rev. Bras. Zool. 23:1002-1009.

BORDIGNON, M.O. \& FRANÇA, A.O. 2009. Riqueza, diversidade e variação altitudinal em uma comunidade de morcegos filostomídeos (Mammalia: Chiroptera) no centro-oeste do Brasil. Chir. Neotrop. 15:425-433.

BORDIGNON, M.O. \& SANTOS, T.M.R. 2010. Ampliação na distribuição de Artibeus obscurus (Schinz, 1822) no centro-oeste do Brasil. Chir. Neotrop. 16:728-731.

BORDIGNON, M.O., SANTOS, T.M.R. \& BERNARDI, I.P. 2011. Ocorrência de Eumops patagonicus Thomas, 1924 no limite dos biomas Chaco e Pantanal, Centro-Oeste do Brasil. Chir. Neotrop. 17:953-956.

CÁCERES, N.C., BORNSCHEIN, M.R., LOPES, W.H. \& PERCEQUILLO, A.R. 2007. Mammals of the Bodoquena Mountains, southwestern Brazil: an ecological and conservation analysis. Rev. Bras. Zool. 24:426-435.

CÁCERES, N.C., CARMIGNOTTO, A.P., FISCHER, E. \& SANTOS, C.F. 2008. Mammals from Mato Grosso do Sul, Brazil. Check List 4:321-335.

CAMARGO, G. 2003. Riqueza e diversidade de morcegos no Pantanal do Miranda-Abobral, Mato Grosso do Sul. Dissertação de Mestrado, Universidade Federal de Mato Grosso do Sul, Campo Grande.

CAMARGO, G. \& FISCHER, E. 2005. Primeiro registro do morcego Mimon crenulatum (Phyllostomidae) no Pantanal, sudoeste do Brasil. Biota Neotrop. 5: http://www.biotaneotropica.org.br/v5n1/ pt/abstract?short-communication + BN00705012005

CAMARGO, G., FISCHER, E., GONÇALVES, F., FERNANDES, G. \& FERREIRA, S. 2009. Morcegos do Parque Nacional da Serra da Bodoquena, Mato Grosso do Sul, Brasil. Chirop. Neotrop. 15:417-424.

COELHO, D.C. 2005. Ecologia e conservação da quiropterofauna no corredor Cerrado-Pantanal. Tese de Doutorado, Universidade de Brasília, Brasília. 
CUNHA, N.L., FISCHER, E., CARVALHO, L.F.A.C. \& SANTOS, C.F. 2009. Bats of Buraco das Araras natural reserve, southwestern Brazil. Biota Neotrop. 9: http://www.biotaneotropica.org.br/v9n4/ pt/abstract?inventory + bn02909042009

CUNHA, N.L., FISCHER, E. \& SANTOS, C.F. 2011. Bat assemblage in savanna remnants of Sonora, central-western Brazil. Biota Neotrop. 11: http//www.biotaneotropica.org.br/v11n3/pt/abstract? inventory + bn 03311032011

DEUS, G.T., BECER, M. \& NAVARRO, I.T. 2003. Diagnóstico da raiva em morcegos não hematófagos na cidade de Campo Grande, Mato Grosso do Sul, Centro Oeste do Brasil: descrição de casos. Ciênc. Agrár. 24:171-176.

EGER, J.L. 1977. Systematics of the Genus Eumops (Chiroptera: Molossidae). Life Sci. Contrib. 110:1-69.

EGER, J.L. 2007. Family Molossidae. In Mammals of South America: Marsupials, Xenarthrans, Shrews, and Bats (A.L. Gardner. eds). The University of Chicago Press, Chicago, p. 400-439.

ERIKSSON, A., GRACIOLLI, G. \& FISCHER, E. 2011. Bat flies on phyllostomid hosts in the Cerrado region: component community, prevalence and intensity of parasitism. Mem. I. Oswaldo Cruz 106:274-278.

ESBÉRARD, C.E.L. \& FARIA, D. 2006. Novos registros de Phylloderma stenops Peters na Mata Atlântica, Brasil (Chiroptera, Phyllostomidae). Biota Neotrop. 6: http://www.biotaneotropica.org.br/ v6n2/pt/fullpaper?bn02506022006 + pt

FABIAN, M. \& GREGORIN, R. 2007. Família Molossidae. In Morcegos do Brasil (N.R. Reis., A.L. Peracchi., W.A. Pedro., I.P. Lima. eds.). Londrina, Paraná, p.149-165.

FERNANDES, G.A. 2009. Fenologia de frutificação e dispersão de sementes por morcegos em mata semidecídua em mesorregião do Pantanal, Brasil. Dissertação de mestrado, Universidade Federal de Mato Grosso do Sul, Campo Grande.

FERREIRA, C.M.M., FISCHER, E. \& PULCHÉRIO-LEITE, A. 2010. Fauna de morcegos em remanescentes urbanos de Cerrado em Campo Grande, Mato Grosso do Sul. Biota Neotrop. 10: http://www.biotaneotropica.org.br/v10n3/pt/ abstract?article + bn02910032010

GARBINO, G.S.T. \& TEJEDOR, A. 2012. Natalus macrourus (Gervais 1856) (Chiroptera: Natalidae) is a senior synonym of Natalus espiritosantensis (Ruschi 1951). Mammalia. 4:1-4.

GARDNER, A.L. 2008. Mammals of South America: marsupials, xenarthrans, shrews, and bats. The University of Chicago Press, Chicago.

GONÇALVES, E. \& GREGORIN, R. 2004. Quirópteros da Estação Ecológica da Serra das Araras, Mato Grosso, Brasil, com o primeiro registro de Artibeus gnomus e A. anderseni para o Cerrado. Lundiana 5:143-149.

GONÇALVES, F., MUNIN, R., COSTA, P. \& FISCHER, E. 2007. Feeding habits of Noctilio albiventris (Noctilionidae) bats in the Pantanal, Brazil. Acta Chiropterol. 9:535-538.

GONÇALVES, F., FISCHER, E., CARVALHO, L.F.A.C. \& FERREIRA, C.M.M. 2012. Polydactyly in the largest New World fruit bat, Artibeus lituratus. Mammal Rev. 42:304-309.

GREGORIN, R. 1998. Extending geographic distribution of Chiroderma doriae Thomas, 1891 (Phyllostomidae, Stenodermatinae). Chirop. Neotrop. 4:98-99.

GREGORIN, R. \& TADDEI, V.A. 2000. Records and taxonomic notes on Molossus and Promops from Brazil (Chiroptera: Molossidae). Mammalia 64:471-476.

GREGORIN, R. \& TADDEI, V.A. 2002. Chave artificial para a identificação de Molossídeos brasileiros (Mammalia, Chiroptera). Mastoz. Neotrop. 9:13-32.

HARRISON, D.L., PENDLETON, N.G. \& HARRISON, G.C.D. 1979. Eumops dabbenei Thomas, 1914 (Chiroptera; Molossidae), a Free-tailed Bat new to the Fauna of Paraguay. Mammalia 43:251.

KISER, W.M. 1995. Eumops underwoodi. Mamm. Species 516:1-4.

LABRUNA, M.B. \& VENZAL, J.M. 2009. Carios fonsecai sp. nov. (Acari, Argasidae), a bat tick from the central-western region of Brazil. Acta Parasitol. 54:355-363.
LIM, B.K., ENGSTROM, M.D., LEE, T.E., PATTON, J.C. \& BICKHAM, J.W. 2004. Molecular differentiation of large species of fruit-eating bats (Artibeus) and phylogenetic relationships based on the cytochrome b gene. Acta Chiropterol. 6:1-12.

LONGO, J.M. 2009. Comunidade de morcegos e de ectoparasitas nas bacias do Miranda e Negro: corredores Cerrado-Pantanal. Tese de Doutorado, Universidade Federal de Mato Grosso do Sul, Campo Grande.

LONGO, J.M., FISCHER, E., CAMARGO, G. \& SANTOS, C.F. 2007. Ocorrência de Vampyressa pusilla (Chiroptera, Phyllostomidae) no Pantanal sul. Biota Neotrop. 7:369-372. http://www. biotaneotropica.org. br/v7n3/pt/abstract?shortcommunication + bn02407032007

LÓPEZ-GONZÁLEZ, C. \& PRESLEY, S.J. 2001. Taxonomic status of Molossus bondae J. A. Allen, 1904 (Chiroptera: Molossidae), with description of a new subspecies. J. Mammal. 82:760-774.

McWILliAMS, L.A., BEST, T.L., HUNT, J.L. \& SMITH, K.G. 2002. Eumops dabbenei. Mamm. Species 707:1-3.

MORATELLI, R., PERACCHI, A.L., DIAS, D. \& OLIVEIRA, J.A. 2011. Geographic variation in South American populations of Myotis nigricans (Schinz, 1821) (Chiroptera, Vespertilionidae), with the description of two new species. Mamm. Biol. 76:592-607.

MUNIN, R.L., COSTA, P.C. \& FISCHER, E. 2011. Differential ingestion of fig seeds by a Neotropical bat, Platyrrhinus lineatus. Mamm. Biol. 76:772-774.

MUNIN, R.L., FISCHER, E. \& GONÇALVES, F. 2012. Food habits and dietary overlap in a phyllostomid bat assemblage in the Pantanal of Brazil. Acta Chiropterol. 14:195-204.

NOGUEIRA, M.R. \& PERACCHI, A.L. 1999. New records of bats from Brazil with a list of additional species for the chiropteran fauna of the state of Acre, western Amazon. Mammalia 63:363-368.

NOGUEIRA, M.R., TAVARES, V. \& PERACHI, A.L. 2003. New records of Uroderma magnirostrum Davis (Mammalia Chiroptera) from southeastern Brazil, with comments on its natural history. Rev. Bras. Zool. 20:691-697.

NOGUEIRA, M.R., PERACCHI, A.L. \& MORATELLI, R. 2007a. Subfamília Phyllostominae. In Morcegos do Brasil, (N.R. Reis., A.L. Peracchi., W.A. Pedro., I.P. Lima. eds.). Londrina, Paraná, p.61-97.

NOGUEIRA, M.R., DIAS, D. \& PERACCHI, A.L. 2007b. Subfamília Glossophaginae. In Morcegos do Brasil (N.R. Reis., A.L. Peracchi., W.A. Pedro., I.P. Lima. eds.). Londrina, Paraná, p. 45-60.

OCHOA, G.J. \& IBANEZ, C. 1985. Distributional status of some bats from Venezuela. Mammalia 49:65-74.

OLIVEIRA, J.A., PESSÔA, L.M., OLIVEIRA, L.F.B., ESCARLATE, F., CARAMASCHII, F.P., LAZAR, A. \& CORDEIRO, J.L.P. 2002. Mamíferos da RPPN Sesc Pantanal. In Conhecendo o Pantanal (L.G. Brandão ed). Sesc Pantanal, Cuiabá, p.33-38.

OLIVEIRA, A.K.M., CONTE, C.O. \& OLIVEIRA-PISSINI, L.F. 2011. Diversidade da quiropterofauna do Instituto de Pesquisas do Pantanal e entorno, Aquidauana, Mato Grosso do Sul, Brasil. R. bras. Bioci. 9:96-102.

ORTÊNCIO FILHO, H., REIS, N.R, \& MINTE-VERA, C.V. 2010. Time and seasonal patterns of activity of phyllostomid in fragments of a stational semidecidual forest from the Upper Paraná River, Southern Brazil. Braz. J. Biol. 70:937-945.

PAGLIA, A.P., FONSECA, G.A.B., RYLANDS, A.B., HERRMANN, G., AGUIAR, L.M.S., CHIARELLO, A.G., LEITE, Y. L.R., COSTA, L.P., SICILIANO, S., KIERULFF, M.C.M., MENDES, S.L., TAVARES, V.C., MITTERMEIER, R.A. \& PATTON, J.L. 2012. Lista anotada dos mamíferos do Brasil. Occasional Papers in Conservation Biology 6:1-76.

PASSOS, F.C., MIRANDA, J.M.D., BERNARDI, I.P., KAKUOLIVEIRA, N.Y. \& MUNSTER, L.C. 2010. Morcegos da região sul do Brasil: análise comparativa da riqueza de espécies, novos registros e atualizações nomenclaturais (Mammalia, Chiroptera). Iheringia Ser. Zool. 100:25-34. 
PERACCHI, A.L. \& NOGUEIRA, M.R. 2007. Família Emballonuridae. In Morcegos do Brasil (N.R. Reis, A.L. Peracchi, W.A. Pedro, I.P. Lima, eds.). Londrina, Paraná, p.27-36.

PERACCHI, A.L. \& NOGUEIRA, M.R. 2010. Lista anotada dos morcegos do estado do Rio de Janeiro, Sudeste do Brasil. Chir. Neotrop. 16:508-519.

PULCHÉRIO-LEITE, A., MENEGHELLI, M. \& TADDEI, V.A. 1998. Morcegos (Chiroptera: Mammalia) dos pantanais de Aquidauana e da Nhecolândia, Mato Grosso do Sul. I. Diversidade de espécies. Ens. cien. 2:167-174.

REDFORD, K. \& EISENBERG, J.F. 1992. Mammals of the Neotropics: the southern cone. Chile, Argentina, Uruguay, Paraguay. University of Chicago Press, Chicago.

RINEHART, J.B. \& KUNZ, T.H. 2006. Rhinophylla pumilio. Mamm. species 791:1-5.

SANTOS, C.F., NOGUEIRA, M., CUNHA, N., CARVALHO, L.F. A.C. \& FISCHER, E. 2010. Southernmost record of the Sanborn's big-eared bat, Micronycteris sanborni (Chiroptera, Phyllostomidae). Mammalia 74:457-460.

SANTOS, T.M.R. \& BORDIGNON, M.O. 2011. Primeiro registro de Tadarida brasiliensis (Geoffroy, I. 1824) para o Pantanal Brasileiro. Chir. Neotrop. 17:832-835.

SCULTORI, C., DIAS, D. \& PERACCHI, A.L. 2009. Mammalia, Chiroptera, Phyllostomidae, Artibeus cinereus: first Record in the state of Paraná, southern Brazil. Check List 5:325-329.

SILES, L., BROOKS, D.M., ARANIBAR, H., TARIFA, T., VARGAS R. J., ROJAS, J.M. \& BAKER, R.J. 2013. A new species of Micronycteris (Chiroptera: Phyllostomidae) from Bolivia. J. Mamm. 94:881-896.

SILVA, A.P. \& MARQUES, S.R. 2010. Morcegos. In Biodiversidade do Pantanal do Poconé (I.M.F. Fernandes, C.A. Signos, J. Penha. eds.). Centro de Pesquisas do Pantanal, Cuiabá, p.169-182.

SILVEIRA, M. 2011. Influência da estrutura da vegetação em morcegos (Mammalia, Chiroptera) no Pantanal da Nhecolândia, Brasil. Dissertação de Mestrado, Universidade Federal de Mato Grosso do Sul, Campo Grande.

SILVEIRA, M., MUNIN, R.L., TOMAS, W.M., FISCHER, E., BORDIGNON, M. \& SILVEIRA, G.A. 2011. The distribution of the spectral bat, Vampyrum spectrum, reaches the southern Pantanal. Biota Neotrop. 11: http://www.biotaneotropica.org.br/ v11n1/en/abstract?article + bn02511012011.

SIMMONS, N.B. 2005. Order Chiroptera. In: Mammal species of the world: a taxonomic and geographic reference (D.E. Wilson, D.M. Reeder. eds.). Smithsonian Institution Press, Baltimore, p.312-529.

SOUZA, J., PAVÉ, R. \& CALDERÓN, M.L. 2008. Primer registro de Eumops dabbenei (Thomas, 1914) (Chiroptera, Molossidae) para la provincia de Entre Ríos, Argentina. Mastozool. Neotrop. 15:189-191.

TADDEI,V.A \& UIEDA, W. 2001. Distribution and morphometrics of Natulus stramineus from South America (Chiroptera, Natalidae). Iheringia Ser. Zool. 91:123-132.
TAVARES, V.C., GREGORIN, R. \& PERACCHI, A.L. 2008. A diversidade de morcegos no Brasil: lista atualizada com comentários sobre distribuição e taxonomia. In Morcegos no Brasil: Biologia, Sistemática, Ecologia e Conservação (S.M. Pacheco., R.V. Marques., C.E.L. Esbérard. eds.). Armazém Digital, Porto Alegre, p.25-60.

TAVARES, V.C., AGUIAR, L.M.S., PERINE, F.A., FALCÃO F.C. \& GREGORIN, R. 2010. Bats of the state of Minas Gerais, southeastern Brazil. Chir. Neotrop. 16:675-705.

TEIXEIRA, R.C., CORREAA, C.E. \& FISCHER, E. 2009. Frugivory by Artibeus jamaicensis (Phyllostomidae) bats in the Pantanal, Brazil. Stud. Neotrop. Fauna Environ. 44:7-15.

VELAZCO, P.M. \& PATTERSON, B.D. 2008. Phylogenetics and biogeography of the broad-nosed bats, genus Platyrrhinus (Chiroptera: Phyllostomidae). Mol. Phylogenet. Evol. 49:749-759.

VELAZCO, P.M., GARDNER, A.L. \& PATTERSON, B.D. 2010a. Systematics of the Platyrrhinus helleri complex (Chiroptera: Phyllostomidae) with descriptions of two new species. Zool. J. Linn. Soc. 151:789-812.

VELAZCO, P.M., AIRES, C.C., CARMIGNOTTO, A.P. \& BEZERRA, A.M.R. 2010b. Mammalia, Chiroptera, Phyllostomidae, Vampyrodes caraccioli (Thomas, 1899): range extension and revised distribution map. Check List 6:49-51.

VIEIRA, C.O.C. 1945. Sobre uma coleção de mamíferos de Mato Grosso. Archos Zool. S. Paulo 4:395-429.

VIVO, M., CARMIGNOTTO, A.P., GREGORIN, R., HINGSTZAHER, E., IACK-XIMENES, G.E., MIRETZKI, M., PERCEQUILLO, A.R., ROLLO, M.M., ROSSI, R.V. \& TADDEI, V.A. 2011. Checklist dos mamíferos do Estado de São Paulo, Brasil. Biota Neotrop. 11: http://www.biotaneotropica. org.br/v11n1a/pt/fullpaper?bn0071101a2011 + pt.

WAIDEMAN, E., UIEDA, W. \& CARVALHO, M.C. 2011. Predação oportunística do bem-te-vi (Pitangus sulphuratus) em Eumops patagonicus (Molossidae) na região do pantanal de Corumbá, Mato Grosso do Sul. Chir. Neotrop. 17:177-179.

WILLIAMS, S.L., WILLIG, M.R. \& REID, F.A. 1995. Review of the Tonatia bidens complex (Mammalia: Chiropera), with descripetions of two new species. J. Mammal. 76:612-626.

WILLIG, M.R., PRESLEY, S., OWEN, R. \& LÓPEZ-GONZÁLEZ, C. 2000. Composition and structure of bat assemblages in Paraguay: a subtropical-temperate interface. J. Mammal. 81: 386-401.

ZANON, C.M.V. 2010. Partição de recursos alimentares entre os morcegos (Mammalia, Chiroptera) da planície de inundação do alto rio Paraná (Mato Grosso do Sul, Brasil) e a influência de pequenos fragmentos na sua diversidade. Tese de doutorado, Universidade Estadual de Maringá, Maringá.

ZORTÉA, M. 2007. Subfamília Stenodermatinae . In Morcegos do Brasil (N.R. Reis., A.L. Peracchi., W.A. Pedro., I.P. Lima. eds.) Londrina, Paraná, p.107-128. 